Article

\title{
On the Significance of Salt Modelling-Example from Modelling of Salt Tectonics, Temperature and Maturity Around Salt Structures in Southern North Sea
}

\author{
Ivar Grunnaleite ${ }^{1, *(1)}$ and Arve Mosbron ${ }^{2}$ \\ 1 Tectonor AS, P.O. Box 8034, NO-4068 Stavanger, Norway \\ 2 LOTOS Exploration \& Production Norge AS, P.O.Box 132, NO-4068 Stavanger, Norway \\ * Correspondence: ig@tectonor.com
}

Received: 2 July 2019; Accepted: 19 August 2019; Published: 22 August 2019

check for updates

\begin{abstract}
Salt structures are attractive targets for hydrocarbon exploration. Salt can flow as a viscous fluid, act as hydrocarbon seal, and salt-related deformation may create reservoir traps. The high conductivity of salt can be crucial for hydrocarbon maturation in a basin. Here, we present results from the study of salt structures on the Eastern flank of Central Graben, on the Norwegian sector of the North Sea. By using our in-house basin modeling software (BMT ${ }^{\mathrm{TM}}$ ), we modelled the salt structure evolution and the effects of salt on temperature and maturation. Our results show up to $85^{\circ} \mathrm{C}$ cooling due to the salt heat pipe effect. An integrated impact of cooling is the depression of vitrinite Ro by up to $1.0 \%$ at the base of a large salt balloon. Our work shows that it is of critical importance to correctly identify salt volumes and to have a good geological model, and to understand the timing and geometrical evolution of salt structures. This study is, to our knowledge, the most specific analysis of the impact of salt on basin temperature and maturation published so far, and is an example of how basin modeling in the future should be an integrated part of exploration.
\end{abstract}

Keywords: salt structures; modeling principles; geohistory evolution; temperature effects; conductivity effects on maturation

\section{Introduction}

All over the world, salt structures are found to be potential targets for hydrocarbon exploration [1]. The low density and the viscous nature of salt enable it to deform by buoyancy flow, distorting, and perhaps penetrating sedimentary sequences above it. Hydrocarbons may be trapped under large domes above salt, along salt flanks, under salt over-hangs, or along salt associated faults. The structural traps we see on the present seismic sections are unlikely to be the structures that were in place when hydrocarbons migrated into the area. Thus, reconstructing the evolution of salt structures may be crucial for constraining the filling and spilling of hydrocarbon accumulations. Due to the high thermal conductivity of salt, salt structures act like heat pipes and can dramatically change subsurface temperatures, potentially affecting the timing of hydrocarbon maturation.

For a general overview of principles of salt properties and the concept of salt tectonics, the new textbook of from Reference [2] is recommended.

Simulating the evolution of a salt structure is not straightforward because many different processes and deformation mechanisms are involved. Salt deforms as a viscous fluid, whereas the surrounding sediments typically deform by brittle and/or viscous and elastic mechanisms. Salt movement may be triggered by local faulting or regional extension, compression or strike-slip, differential loading, erosion, dissolution, etc. $[3,4]$, and the mobilization of the salt invokes several other processes that can 
reinforce the salt flowage. Salt flowage and accumulation of salt in central pillows, domes, or diapirs assume withdrawal and thinning of the salt from the surrounding area (e.g., Reference [5]). This again causes increased subsidence and collapse of the overburden, which provides accommodation space for sedimentation, in turn enhancing the salt drive. Likewise, doming and uplift of overburden above the evolving salt may lead to erosion, increasing the gravity instability by removing mass above the thickest part of the salt and loading erosive material on the flanks. The upward movement of salt will apply an upward force on the sedimentary overburden. This effect can create overpressure in certain areas and affect the sealing and fluid-flow properties of a reservoir.

Salt has very unique properties compared to the surrounding sediments.

- It behaves as a plastic material under stress. If the applied stress is equal to or larger than a characteristic yield stress, it will flow or creep. Rock creep needs high temperatures, but salt can creep even at room temperature if it contains water [2].

- Salt has high seismic velocity ( 4500 m/sec. [6]) leading to unreal "velocity pull-up structures" beneath the salt in seismic time-sections.

- The thermal conductivity of salt $(\mathrm{K})$ is up to three times greater than the surrounding sediments [7].

- Salt mobility is dependent on temperature and the amount of water in salt [2]. Dry, cold salt is immobile [8], whereas wet salt at $60^{\circ} \mathrm{C}$ and 280 bar confining pressure only can support $30 \%$ of the confining stress of dry salt (see Reference [9], referred in Reference [10]).

- Salt does not compact like sediments, but have a more or less constant density of $\sim 2.15-2.20 \mathrm{~g} / \mathrm{cm}^{3}$ as a function of depth [11-13] (see Figure 1).

Clastic sediments have lower density at deposition, but compacts rapidly by burial due to the loss of porosity. At 1000-1500 m depth, sediment density equals the density of salt. Thus, with a sediment cover of more than 1000-1500 m salt movement is enhanced by buoyancy. In Reference [12], it is stated that a burial below at least $1600 \mathrm{~m}$ and more typically $3000 \mathrm{~m}$ of siliciclastic sediments is required before the average density of the entire overburden exceeds that of salt, and a diapir is able to reach the surface driven by buoyancy alone.

Salt movement is generally initiated by instability and as long as the sediment load is equally distributed over a flat salt surface, no salt movement will occur.

The density relationship with the depth for salt and surrounding sediments are shown in Figure 1. Lateral instability of the salt could be caused by tectonic events, differential loading, erosion, dissolution, tilting, or folding of the overburden by compression or drag by moving overburden, etc. These factors could create a relief on the surface of the salt sufficient to start movement of salt towards the locally highest point of the salt surface. When the flow of salt has been initiated, it will continue and be self-supported by buoyancy.
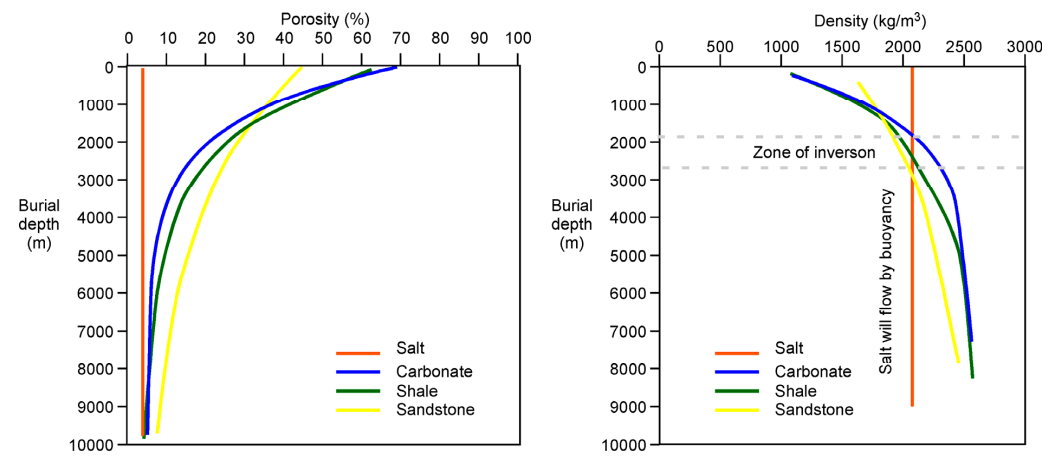

Figure 1. Salt has constant porosityand density, whereas sediments compact and lose porosity as they are buried. When the surrounding sediments have a higher density than salt, buoyancy will drive the upward movement of salt. The curves show the properties of sediments used in the modelling in this paper. 
Salt movement will increase the initial relief, and withdrawal of salt from an area will create accommodation space for more sediments, which again will enhance differential loading-stress. Salt movement will slow, and eventually halt, as the diapir grows tall and reaches levels close to the surface. The lithostatic stress from above is lowered and accordingly plasticity of salt is reduced. At the same time, the effect of buoyancy is lost, and the drag effect and friction from surrounding sediments is increased. The structural evolution of salt has been modeled with both physical and numerical models, but very little is published on the temperature and maturation effects of salt structures except for Reference [14] that modelled these effects on very simple geometries.

This paper reports modeling of salt evolution in Southern North Sea and quantification of the temperature effects around salt diapirs. The modeling was done to quantify the effects on maturation and petroleum potential around the modeled salt structures, and in general to highlight the importance of addressing these effects when exploring for hydrocarbons around salt structures.

\section{Study Area}

The modeled salt structures are situated on the Hidra High (Model 1), and Sørvestlandet High (Model 2) on the platform just East of Central Graben in the Southwestern part of the Norwegian North Sea shelf (Figure 2).

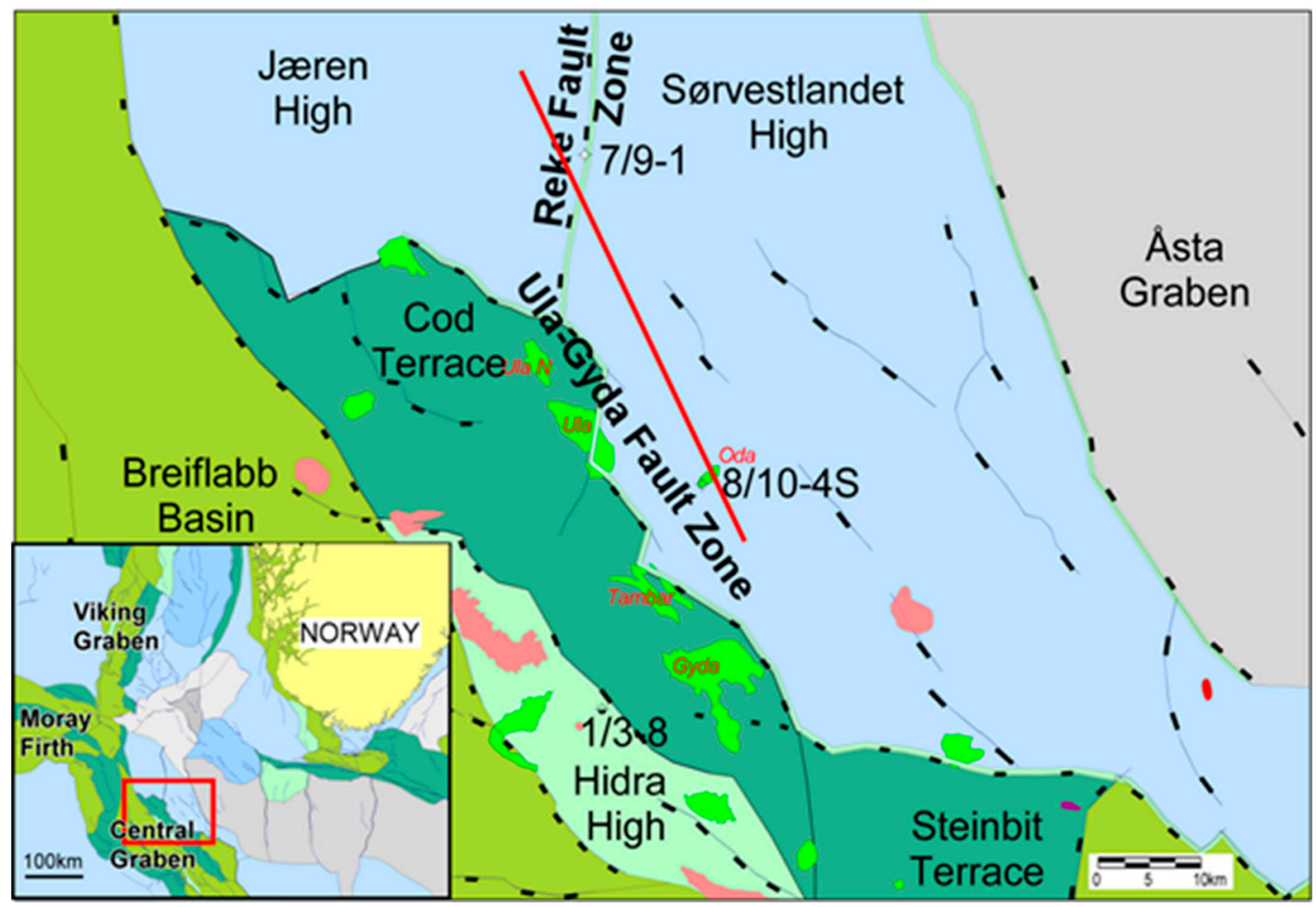

Figure 2. Overview map of the study area situated on the eastern flank of the Central Graben seen as the green basement trend between the blue platform areas. Maps are modified from Norwegian Petroleum Directorate (NPD) maps. The inset map shows the study area situated centrally in the North Sea between mainland UK and Norway. Model 1 is positioned close to Well 1/3-8 on the Hidra High. Model 2 is shown by the red line. Hydrocarbon discoveries are shown in pink and light green.

Several oil fields (Mime, Ula, Tambar and Gyda) on the Cod Terrace and Sørvestlandet High and other discoveries in the areas are situated over salt structures with reservoirs in Upper Jurassic Ula sandstone [15]. On the Hidra High, several hydrocarbon discoveries are made including gas and oil in Late Paleocene Forties Formation (Oselvar, Ipswich), gas in Late and Early Cretaceous (1/3-1) and oil and gas condensate in Jurassic reservoirs (King Lear, Romeo). The Sørvestlandet area is dominated by pod-interpod salt structures [16-19]. Pods are irregular rounded basin filled with Triassic sediments 
and distributed in a matrix of Zechstein salt forming walls, diapirs, ridges, and highs in a polygonal hive-pattern between the pods (Figures 3 and 4). The pods are capped by Jurassic to Cretaceous sediments. A system of collapse grabens in the Cretaceous unit follows the salt ridges surrounding the pod basins as can be seen in Figures 5 and 6 . Their positions indicate a development related to vertical movement of salt structures and coeval subsidence in the pod basins.

The hydrocarbon potential in this area is related to Upper Jurassic reservoir rocks above structures defined by salt tectonics. A thick, more or less uniform salt unit was deposited over the entire area in Permian time, and has gradually developed into the complex salt structures we see today. Their development is related to episodes of salt movement from Early Triassic to Neogene time (Figure 4). The Model 2 profile crosses the Oda structure (well 8/10-4S) where oil is discovered in the Ula sandstone above a large salt structure. Other structures in the area have proven to be dry, thus it is of great importance to increase the understanding of the evolution and stratigraphy of similar undrilled structures in this area.

\section{Geology}

\subsection{Stratigraphy}

A standardized stratigraphic column for the Central Trough area is shown in Figure 3. The geological development in the greater Central Through area starts with clastic deposits of Paleozoic rocks, Devonian and Permian Rotliegend strata, as observed in the Embla field (block 2/7). The Paleozoic strata are generally interpreted to be continental and arid deposits. At the end of the Paleozoic (Late Permian time), the entire Southern North Sea basin developed into a large evaporitic basin; the northern Zechstein basin, with relatively thick and widespread salt and evaporite deposits.

The Mesozoic commenced with Triassic deposition, believed to be dominantly continental, and additional accommodation space is generated from Permo-Triassic rifting. The Triassic sediment thickness is generally significant. On the UK "J-block" (on Josefine Ridge), just West of the study area, productive Triassic intervals are exploited, and productive Triassic sandstones are present in the Ula field (7/12) and at the Gaupe field (block 6/3). The significant thickness of the Triassic actually commenced halokinesis of the Zechstein group salt by the Middle to Late Triassic time.

The Jurassic saw the introduction of marine sedimentary environments in the Central Trough area, but after the deposition of the terrestrial Bryne Formation. The Upper Jurassic is clearly marine and the Ula Formation yield several producing fields. The Mandal Formation, plus partly the Farsund and Haugesund Formations, are the dominant source rocks for the petroleum in the area. Strong rifting occurred in the Late Jurassic.

The Cretaceous is totally marine with marly and shaly deposits of the Cromer Knoll Group (Lower Cretaceous) and chalky deposits of the Shetland (or Chalk) Group (Upper Cretaceous). The Cretaceous sediments were deposited in a passive setting, without rifting. The Chalk strata exhibit significant production, notably from the Ekofisk Field in block 2/4. In the Tertiary, the passive and relatively deep marine sedimentation continued, shale is the dominant lithology. However, sandy systems, especially the Forties Formation system, reached the study area and comprise several fields; Blane, Cod and Oselvar have all produced from the Paleocene Forties Formation.

\subsection{Triassic Pod Basins}

It is known from literature that salt movement in this area started already in Early Triassic and the large salt-structures were clearly defined before deposition of the interpreted Cretaceous and younger horizons, see e.g., References $[3,19,20]$.

Our interpretation and analysis of the Triassic sequences also revealed that the major salt structures were established already in the Early Triassic time (Figure 4). Their position is closely related to faults in the pre-salt sequence. Late Permian to Early Triassic tension, possibly related to movement along the Tornquist Zone $[20,21]$, leads to extensional faulting. The faulting created a surface relief on the 
salt, which focused the deposition into depressions that gradually developed into deep basins. As a surface relief was created, and the sediment load was enough to apply a stress above the yield stress, the lower part of the salt deformed plastically and started to move. Once the areas of deposition and areas of salt growth were fixed, the structures were exaggerated by repeating this salt flow pattern for each deposited sedimentary sequence in a self-supporting system. During Triassic time, the deposition concentrated in circular sag-basins or pods between more or less evenly spaced salt diapirs and ridges. This is seen especially in the North of the Ula Fault (Figures 5 and 6) on the Cod Terrace and Sørvestlandet High. Between the sag basins, relatively lower "salt-saddles" acted as salt-feeders into the main salt structures that develop where salt walls and saddles join up in the corners of a polygon pattern. The modeled profile in this study crosses several pod-basins and salt saddles north of the Ula -Gyda Fault Zone (Figures 2 and 5), close to the top of the salt structures 7/9-1 and Oda.

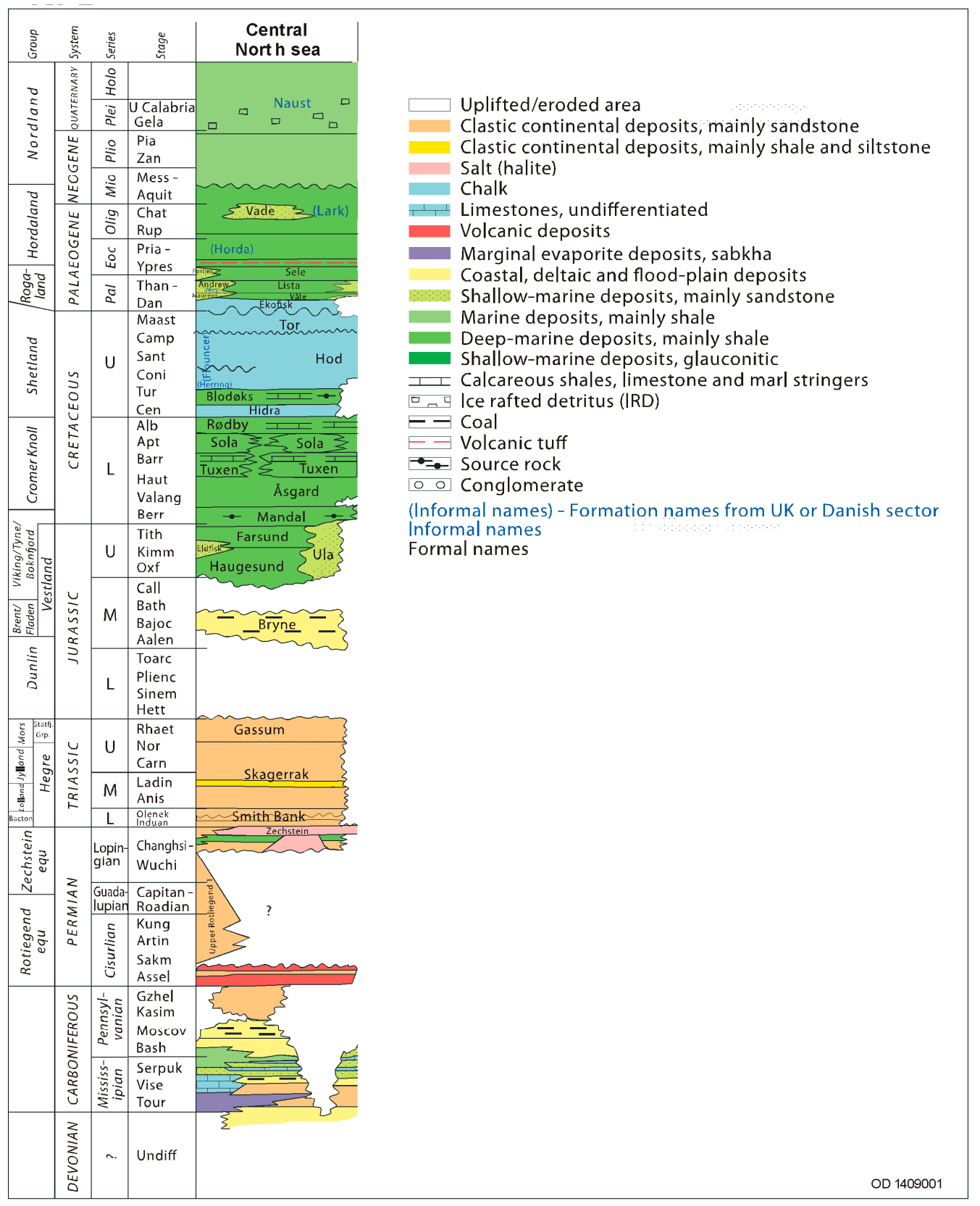

Figure 3. Stratigraphic column from the Central Trough area, modified from Norwegian Petroleum Directorate (www.npd.no). 


\section{1) End Permian}

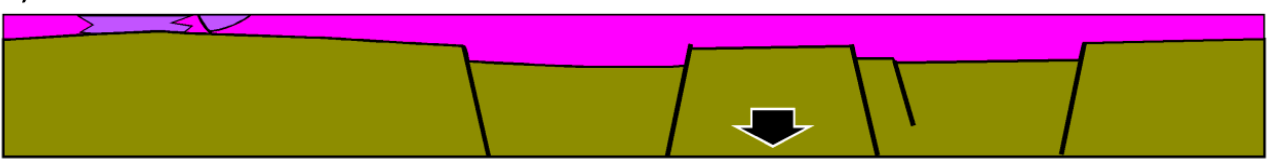

\section{2) Early-middle Triassic}

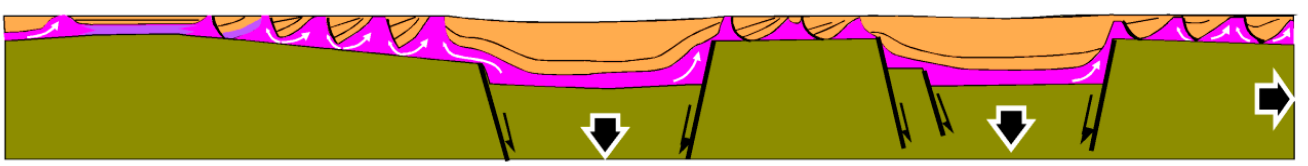

\section{3) End Triassic}

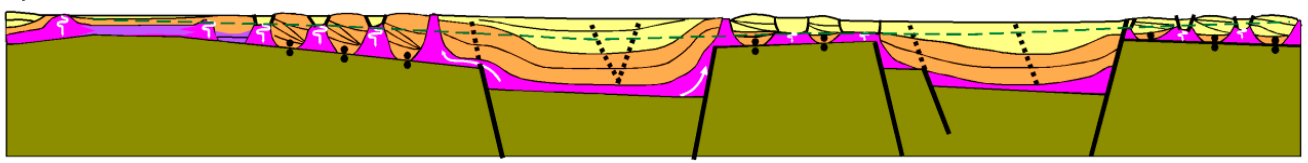

\section{4) Late Jurassic}

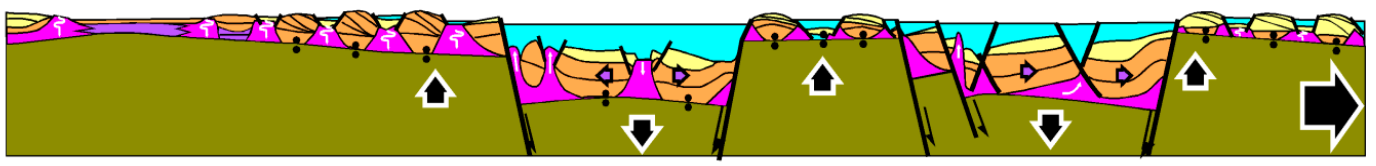

\section{5) Early Cretaceous}

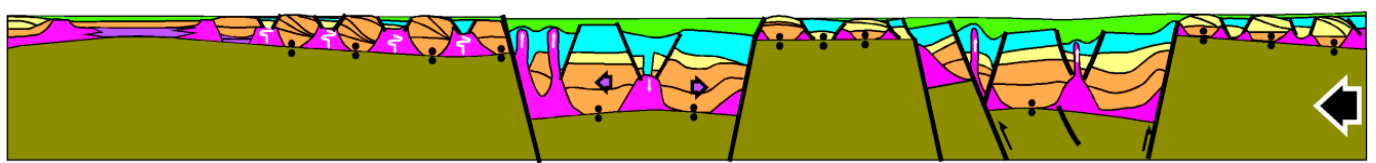

\section{5) Eocene- Oligocene}

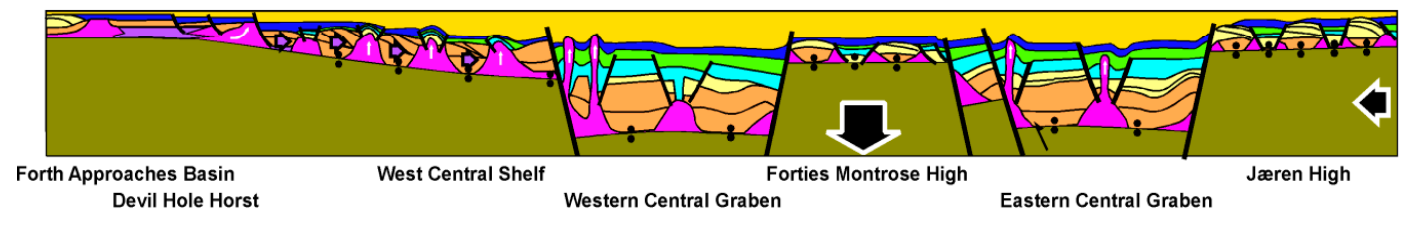

\begin{tabular}{ll}
$\square$ Tertiary & Chalk \\
\hline$\square . C r e t a c e o u s$ & Jurassic \\
Skagerrak (L.Triassic) & Smith Bank (E. Triassic) \\
Zechstein salt & Zechstein carbonate/anhydrite \\
Basement
\end{tabular}

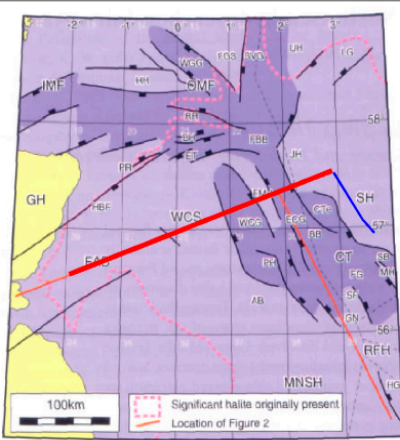

Figure 4. General section across the Central Graben showing the sequential evolution of salt structures. The study area is situated on the Jæren High to the right on this figure. The inset map shows the position of the regional transect in red. The Figure is modified from Reference [3]. The modeled structures of this study are based on typical structures from Eastern Central Graben (Model 1) and Jæren High (Model 2) whose position is shown as a blue line. 


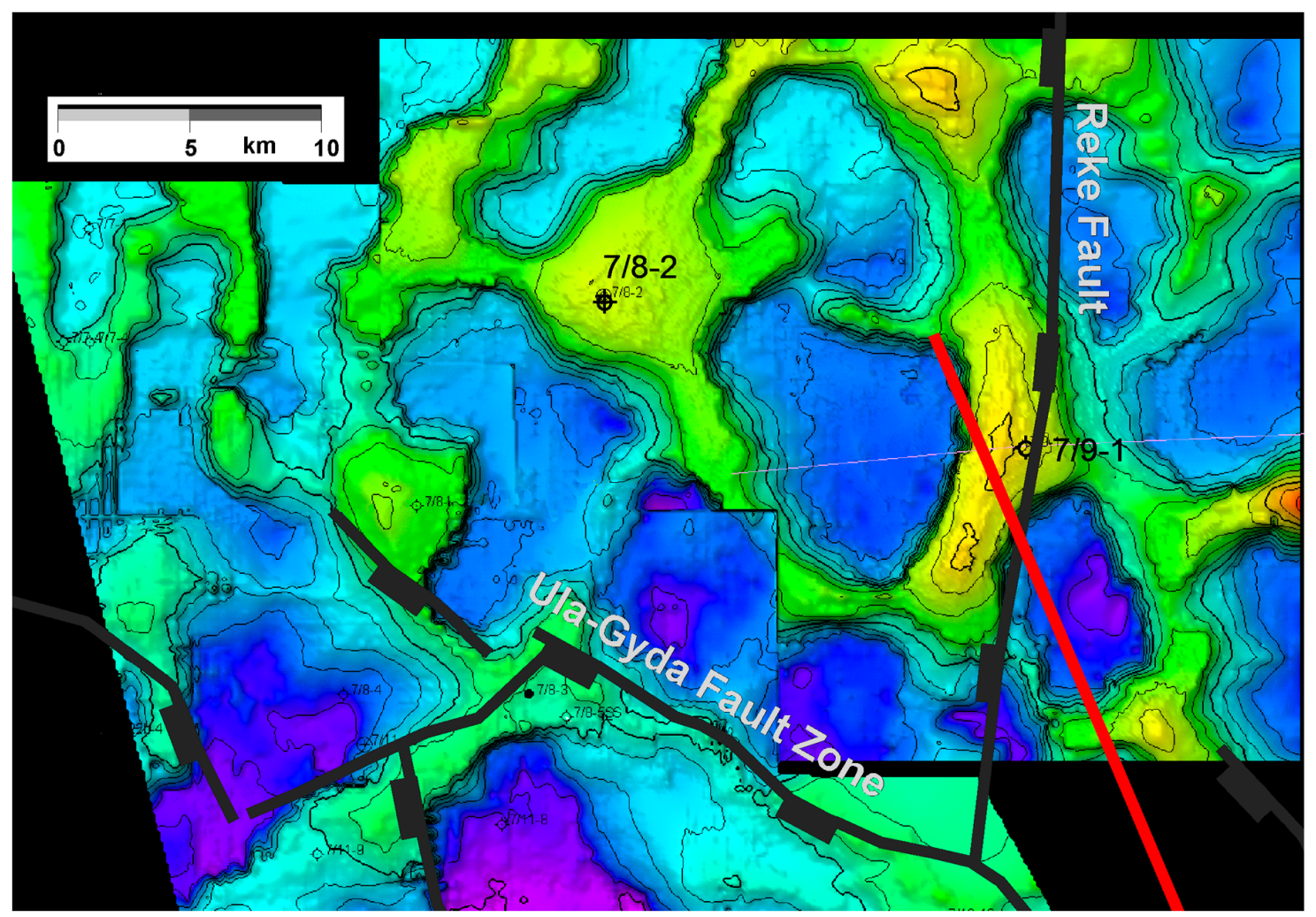

Figure 5. Top Zechstein salt map showing typical Triassic pod basins (in blue colours) surrounded by a polygonal pattern of salt walls and highs (in green-yellow colour). The red line shows the position of the Northern part of Model 2.

\subsection{Cretaceous Collapse Grabens}

On the Base Cretaceous map (Figure 6), a characteristic polygonal pattern of grabens between the salt structures defines the flexure between polygonal sag basins or "pods" around the salt structures. The collapse grabens all appear in the Cretaceous above the "salt-saddles" or supra salt [19], and this may be related to a Cretaceous phase of regional tilting and inversion (Figure 7), as suggested by Reference [3] and others. Figure 4 shows a change from extension to compression in Early Cretaceous.

The WNW-ESE striking grabens seem to be the best developed, indicating a tensional stress direction of SSW-NNE. If this stress was compressive, the relative high saddle-ridges acting as salt feeders between the sag basins would be compressed and experience longitudinal extensional faulting in the upper part due to bending. Concurrently, subsidence would be increased in the sag-basins ("pods") and sedimentation would resume (Figure 7). This inversion phase would thus lead to increased salt movement and basin subsidence. Furthermore, this may have resulted in salt withdrawal from the pod-defining ridges when salt moved into the major salt diapirs and later caused graben collapse in these areas. Longitudinal narrow horsts are observed on top of some of the major salt structures (Figure $8 \mathrm{~b}$ ). These may have developed as normal faults simultaneously with the graben development, but later developed into horsts due to upward salt movement. As salt moves into the highest structure, salt is withdrawing from the lower connected saddle ridges. As a consequence, the extensional faults on these saddles developed into grabens due to net salt withdrawal here. 


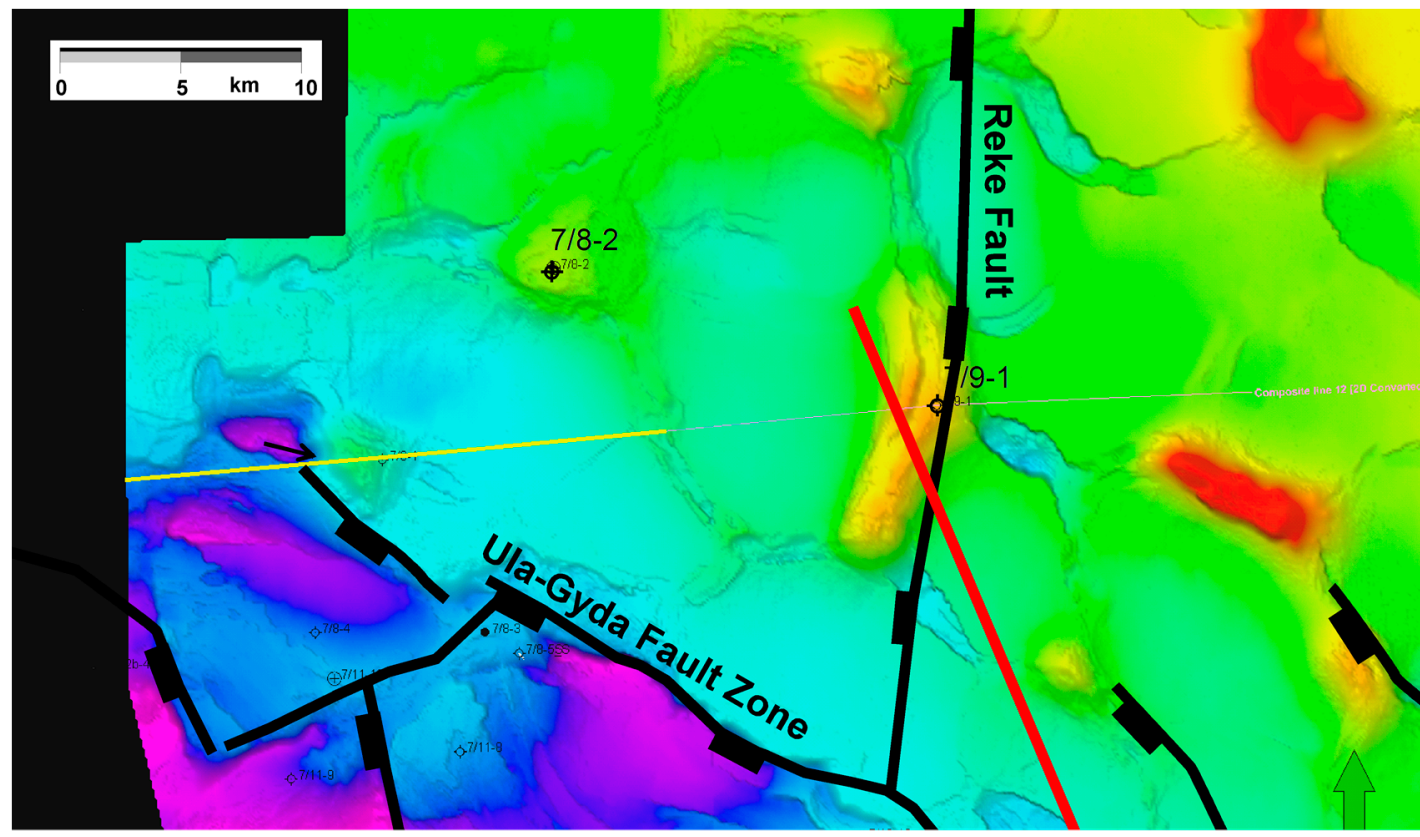

Figure 6. Base Cretaceous (BCU) time map provided by Lotos showing Cretaceous collapse grabens North of the Ula Fault. The Triassic sag-basins or pods are the polygonal flat areas between positive salt-structures and supra-salt collapse grabens. The arrows indicate the direction of salt movement away from the collapsing grabens accumulating into the growing salt diapirs. Red colors define the shallowest areas, and purple defines the deepest areas. Red line shows the Northern part of Model 2.
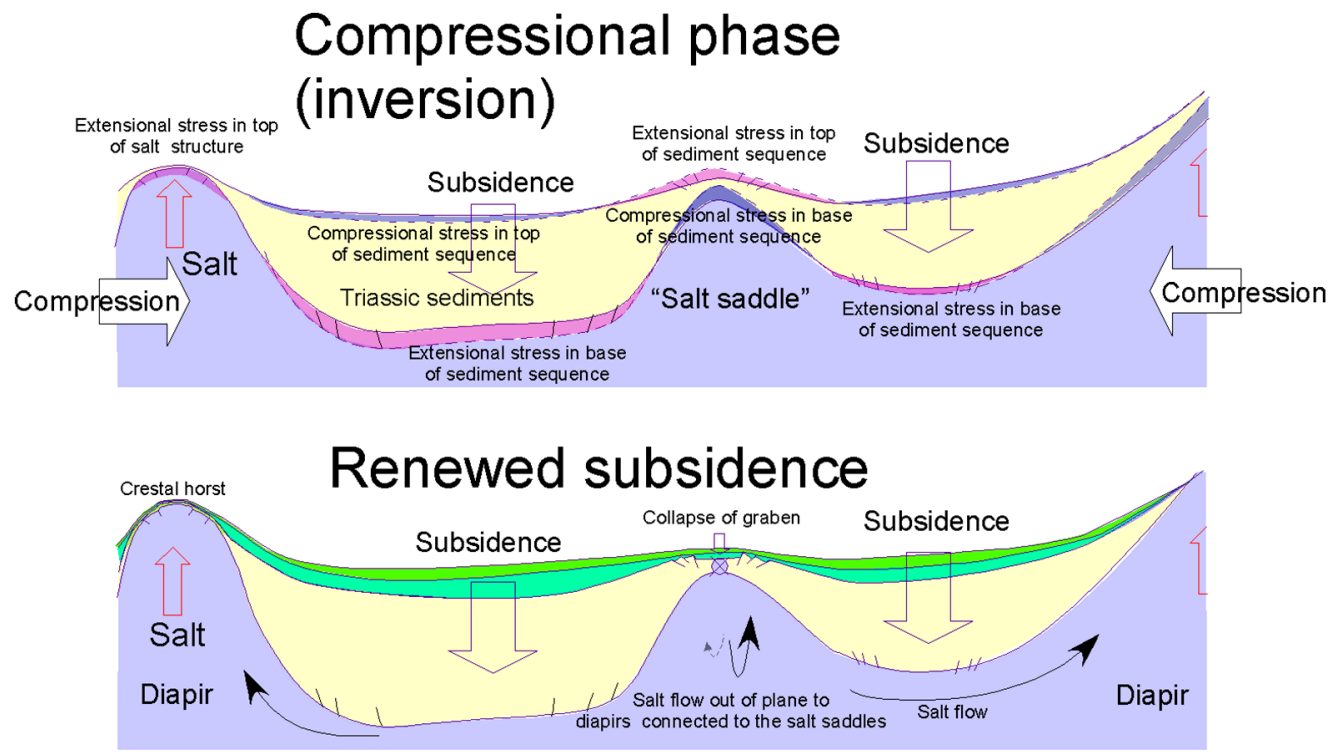

Figure 7. Principle sketch showing how a compressional stress regime would affect basins, salt saddle and diapir area. Extensional stresses above the saddle area act as a hinge between subsiding basins. Extensional faults will follow the length axis of the saddle areas and could collapse when compression ceases and renewed subsidence occurs. This could also explain the existence of crestal horsts seen on the major salt structures (Figure 8). 


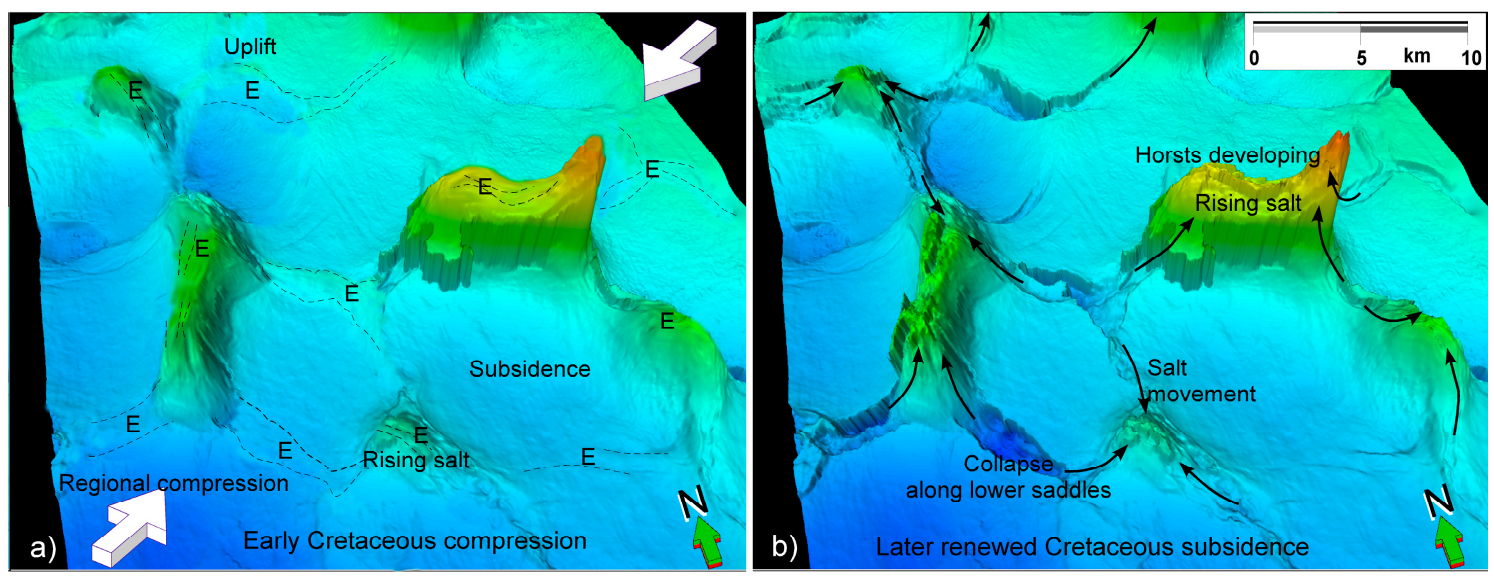

Figure 8. (a) Effect of Early Cretaceous compression from SW on an unfaulted surface. Blue arrows indicate areas with increased subsidence, red arrows show areas with increased uplift. In the saddle areas between basins and over the highest salt structures extensional faults will occur, as indicated by the stippled lines and marked by E. The background figure is based on the BCU surface and is manipulated in a photo editor to mimic a smoother pre-faulting surface. (b) Effect of renewed subsidence. Collapse grabens (most prominent along the WNW-ESE trend) have developed along the salt saddles. Horsts are developed on the highest salt structures. Background figure is an unedited BCU surface interpreted by LOTOS.

\section{Salt Reconstruction Modelling}

\subsection{Methods}

The 2D modeling reported in this section was performed by the use of our in-house basin modeling software BMT (see References [22,23], for more details). The following functionalities in BMT have been used here:

i. Reconstruction of the geohistory. The geohistory reconstruction is carried out by a decompaction technique in which the layers are removed one-by-one and corrections are made for the present day compacted thicknesses. The decompaction technique (generally combined with fault-restoration) gives a number of 2D 'time-slices' of the basin development.

ii. Calculation of temperature and maturity history. The calculation is based on the reconstructed geohistory (in i.) using a finite-difference grid. Input for the modeling is paleo heat flow from the mantle, surface temperature history, thermal conductivities, and heat capacities of the sediments. The calculation of vitrinite reflectance is using EASY\%RO model.

From an initial sediment composition at the surface, the porosity in a sedimentary basin will be reduced and the density increased as a function of increasing stress and temperature. Empirically, the final porosities in many lithologies show an exponential decline with depth. The calculation of porosities in sedimentary basins is thus often done by using exponential lithology-specific porosity-depth relations. These are typically given the form:

$$
\phi=\phi_{\mathrm{o}} \exp (-\mathrm{cz})
$$

where $\phi$ is porosity (fraction), $\phi_{\mathrm{o}}$ is the surface porosity (fraction), $\mathrm{c}$ is a constant, and $\mathrm{z}$ is the depth in $\mathrm{km}$ (see e.g., Reference [24]). The porosity parameters used in this modeling study are shown in Table 1.

The salt movement is simulated during backstripping by manual editing of the salt geometry at every appropriate time step. This is accomplished by two methods (Figure 9) that can be combined: (1) Changing the lithology of a polygon at a given time ("litho-switching") and (2) "inflating" or "deflating" salt polygons ("mass editing"). 
Litho-switching allows adding or removing portions of a salt body to mimic salt growth or withdrawal. It is used when a salt body completely pierces overlying sediments or when the salt body grows horizontally, for example. For more details, see Reference [23].

Inflation and deflation technique allows the size and shape of a single salt polygon or a set of salt polygons to be changed (Figure 9c). A polygon is inflated or deflated by increasing or decreasing the length of the selected grid line, which is connected along the upper and lower boundaries of a polygon. For more details, see Reference [23]. When a selected grid line is inflated or deflated, it will remain fixed with respect to one of these boundaries while moving the other boundary upwards or downwards. The polygons may be vertically inflated to many times their original height or deflated to a thickness of less than one meter.

The mass added or removed by litho-switching is not accounted for in the modeling. For example, if the lithology of a polygon is switched from salt to shale during reconstruction, the added shale mass is not automatically deducted from elsewhere in the shale unit. In essence, the mass of a polygon that has been litho-switched spontaneously appears or disappears. However, BMT quantifies the area of selected polygons allowing the user to keep track of (and account for) the area added or removed by litho-switching. Anyway, as salt movement by nature is three-dimensional with mass moving in and out in all directions, there is no reason to keep volume-edited area constant in these 2D profiles.
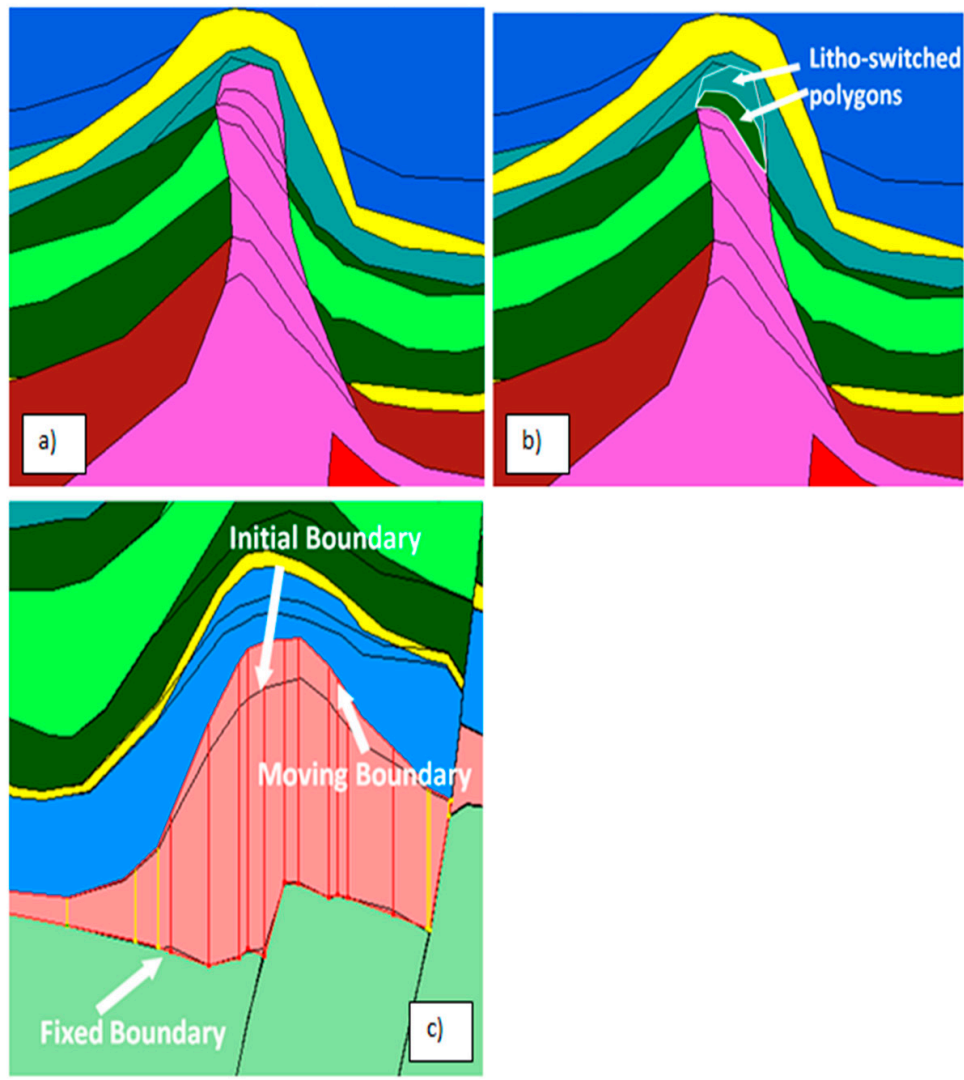

Figure 9. Illustrations of methods for modeling salt movement in the BMT modeling software. $(\mathbf{a}, \mathbf{b})$ litho-switching. The salt lithology for a polygon is changed at a given time. (c) Mass-editing by polygon inflation. The selected vertical in red color, are extended above the upper (moving) boundary while remaining fixed along the lower boundary. Note how overlying polygons are pushed upwards.

\subsection{Geohistory Reconstruction}

We are modeling the geohistory, temperature, and maturity development on two profiles from the Eastern margin of the Central Graben, in the Norwegian part of the North Sea. The first profile 
(Model 1) is only $11 \mathrm{~km}$ long and includes a single salt structure. The second profile (Model 2) is $56 \mathrm{~km}$ long and includes five salt structures (see Figure 2 for locations).

\subsubsection{Model 1}

Model 1 is one single balloon-shaped salt structure from the Hidra High (Figure 10). The salt structure geometry of Model 1 was based on an interpreted seismic section close to a well 1/8-3 on the Hidra High on the North-Eastern flank of the Central Graben (Figure 2).

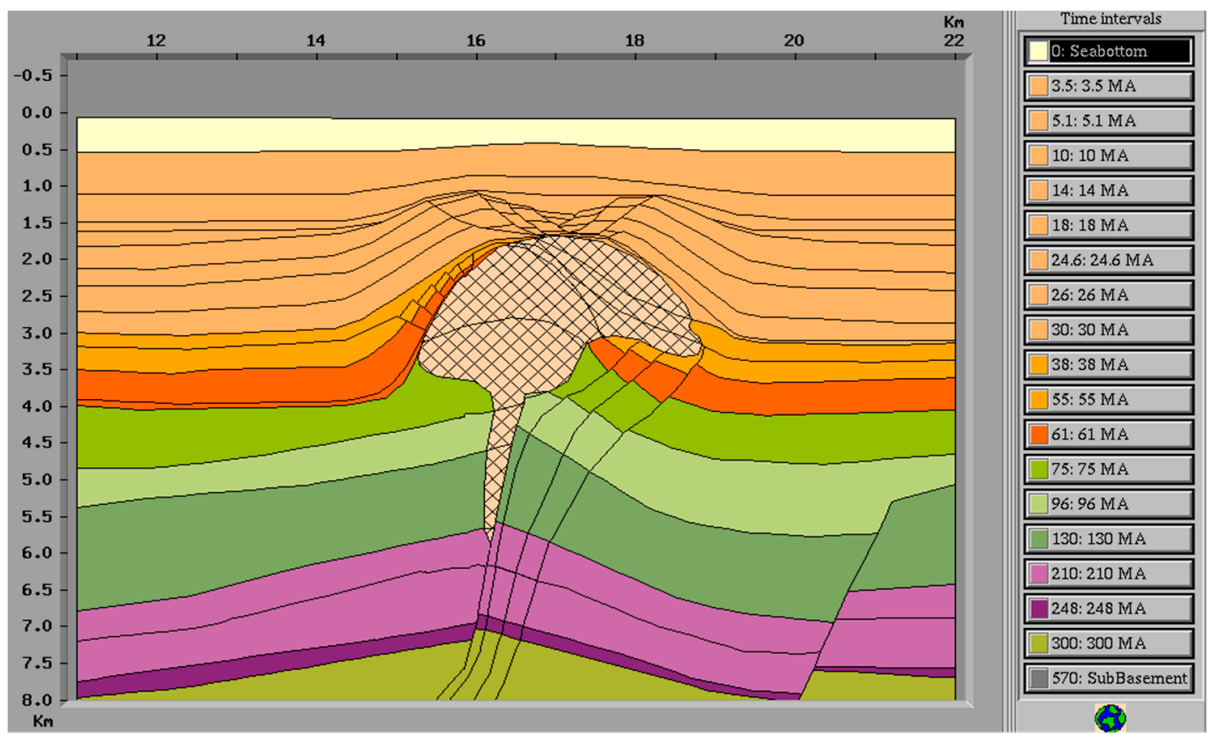

Figure 10. Interpreted present-day geometry of Model 1. Units are coloured by age. Ex situ salt volume is marked by cross-hatching. In situ salt coloured dark purple as defined by age interval (248-300 Ma).

Figure 11 shows the reconstructed geohistory combining litho-switching and mass-editing to enable both upward and later horizontal movement of the salt volume into an overhang. The lithology input parameters are shown in Table 1. The salt movement is initiated along a fault zone and once a relief on the salt surface is established in Triassic time upward movement of salt continuous through Cretaceous time when a vertical salt diapir of more than $5 \mathrm{~km}$ height was established. Increasingly differential loading lead to a skewed development of the top salt bulb, bending it over and developing it into a hemisphere asymmetrically placed relative to its now dramatically thinned and broken stem during Paleogene to Cenozoic evolution.

Table 1. Lithology parameters used in the basin modeling.

\begin{tabular}{lllll}
\hline Lithology & $\begin{array}{l}\text { Surface Porosity } \\
\mathbf{F}_{\mathbf{0}}\end{array}$ & $\begin{array}{l}\text { Exponential } \\
\text { Porosity Constant } \\
\mathbf{c}\end{array}$ & $\begin{array}{l}\text { Thermal Conductivity } \\
\mathbf{( W / m K})\end{array}$ & $\begin{array}{l}\text { Specific Heat } \\
\text { Capacity } \\
\text { (J/kg K) }\end{array}$ \\
\hline $\begin{array}{l}\text { Claystone and } \\
\text { siltstone }\end{array}$ & 0.63 & 0.51 & $\begin{array}{l}1.7(6 \% \text { porosity }) \\
1.0(60 \% \text { porosity })\end{array}$ & 940 \\
Shale & 0.63 & 0.51 & $\begin{array}{l}2.8(6 \% \text { porosity }) \\
1.2(60 \% \text { porosity })\end{array}$ & 1190 \\
Chalk & 0.70 & 0.71 & $\begin{array}{l}2.04(13 \% \text { porosity }) \\
1.23(38 \% \text { porosity })\end{array}$ & 1090 \\
Sandstone Jurassic & 0.37 & 0.58 & $\begin{array}{l}2.04(13 \% \text { porosity }) \\
1.23(36 \% \text { porosity })\end{array}$ & 1090 \\
Sandstone Triassic & 0.49 & 0.27 & $\begin{array}{l}3.4(6 \% \text { porosity }) \\
2.5(40 \% \text { porosity })\end{array}$ & 1080 \\
Salt & 0.04 & 0.05 & $\begin{array}{l}5.1(3 \% \text { porosity }) \\
5.0(4 \% \text { porosity })\end{array}$ & 1060 \\
Basement & 0.04 & 0.05 & $3.1(3 \%$ porosity $)$ & 1100 \\
\hline
\end{tabular}



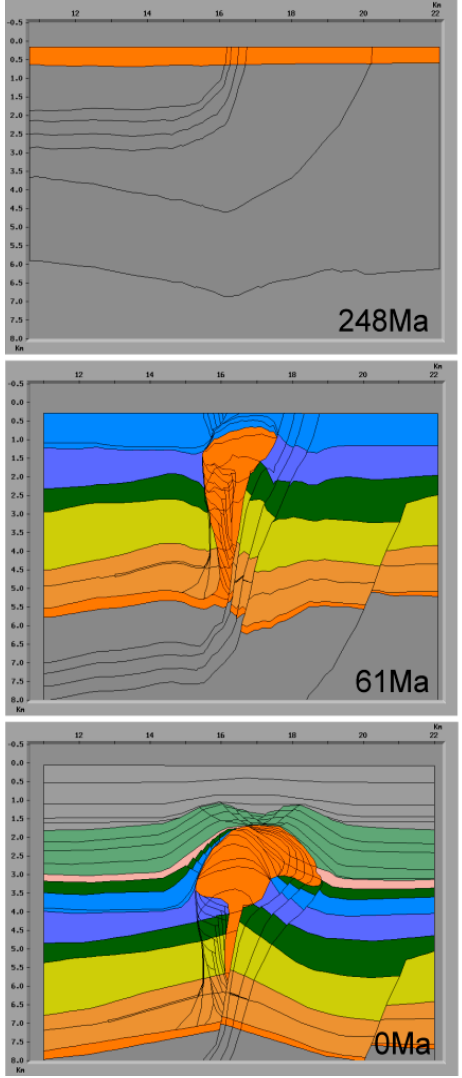
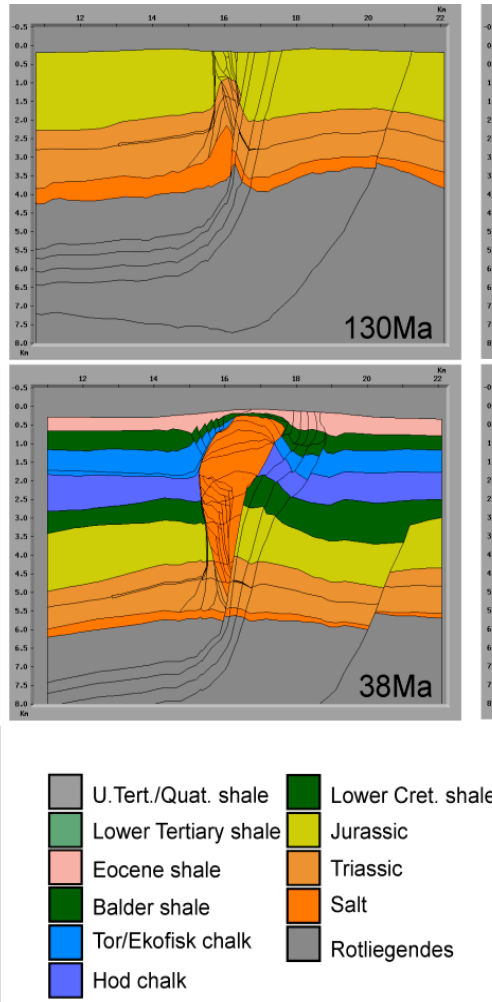

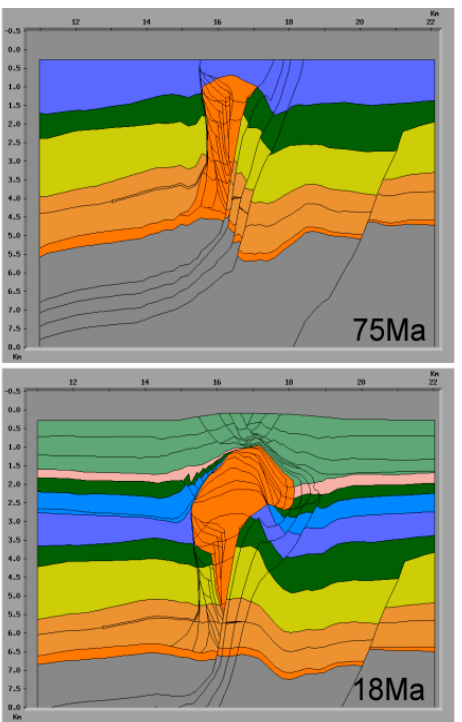

Figure 11. Reconstructed geohistory of Model 1, showing the stepwise evolution from a uniform salt layer to the present day salt balloon. The figure is colored based on the lithologies used in the model. The main salt volume protrudes through the Ekofisk and Hod chalks (in purple and blue) and is capped by Cenozoic shales.

\subsubsection{Model 2}

Model 2 is based on a NNW-SSE striking seismic section across Jæren High and Sørvestlandet High on the Eastern flank of Central Graben (Figure 2). The profile extends SSE-wards from the salt structure near well 7/9-1 in the Southeastern part of Jæren High, and crosses the N-S striking Reke Fault Zone, continues along the Southeastern part of Sørvestlandet High, until it ends after crossing the Oda salt structure (well 8/10-4S) in the Oda Field.

The model was based on interpreted and depth-converted seismic sections and maps shown in Figure 12. The seismic section was interpreted by LOTOS down to Base Cretaceous (BCU) and top and base of the salt. The interpretations of the salt structures are based on clear folding or penetration of Jurassic to Cenozoic sequences at the top, often with associated high amplitude reflection above the top of the salt structures (caused by the presence of anhydrite). Down-flank, the interpretation is much more uncertain as the seismic data are very transparent both in the salt and in the surrounding Triassic units. The base of major salt structures is defined by the width of the velocity pull-ups observed below the salt (Figure 12a).

The lack of regional seismic correlation markers within the continental Triassic units and the low impedance contrast between Zechstein salt and Triassic pod units make interpretation and correlation between pods difficult [17]. For the Triassic sequences, no ages were known. For the modeling, 14 Triassic sequences were interpreted and given ages evenly distributed between $248 \mathrm{Ma}$ and $205 \mathrm{Ma}$.

The profile has five separate salt structures becoming increasingly more prominent throughout Triassic times, as sedimentation focus on small semi-circular pod-basins pushing the salt into the ridges between them. The distribution of these pods can be seen on the Top Zechstein map (Figure 5) and less pronounced on the Base Cretaceous (BCU) map of Figure 12b, best developed North of the 
Ula-Gyda Fault Zone. The Triassic pod basins probably became welded to the pre-salt unit as salt was completely removed below these pod basins during Jurassic to Cretaceous times. The smallest structures seem to cease moving during Late Triassic to Jurassic times, whereas the largest structures (i.e., 7/9-1 structure and Oda structure (8/10-4)) seem to have been actively growing well into Cenozoic time. Note the grabens in the Cretaceous unit above the central salt structures (Figure 12a), also seen as green lens-shaped depressions on the Base Cretaceous map (Figure 12b).
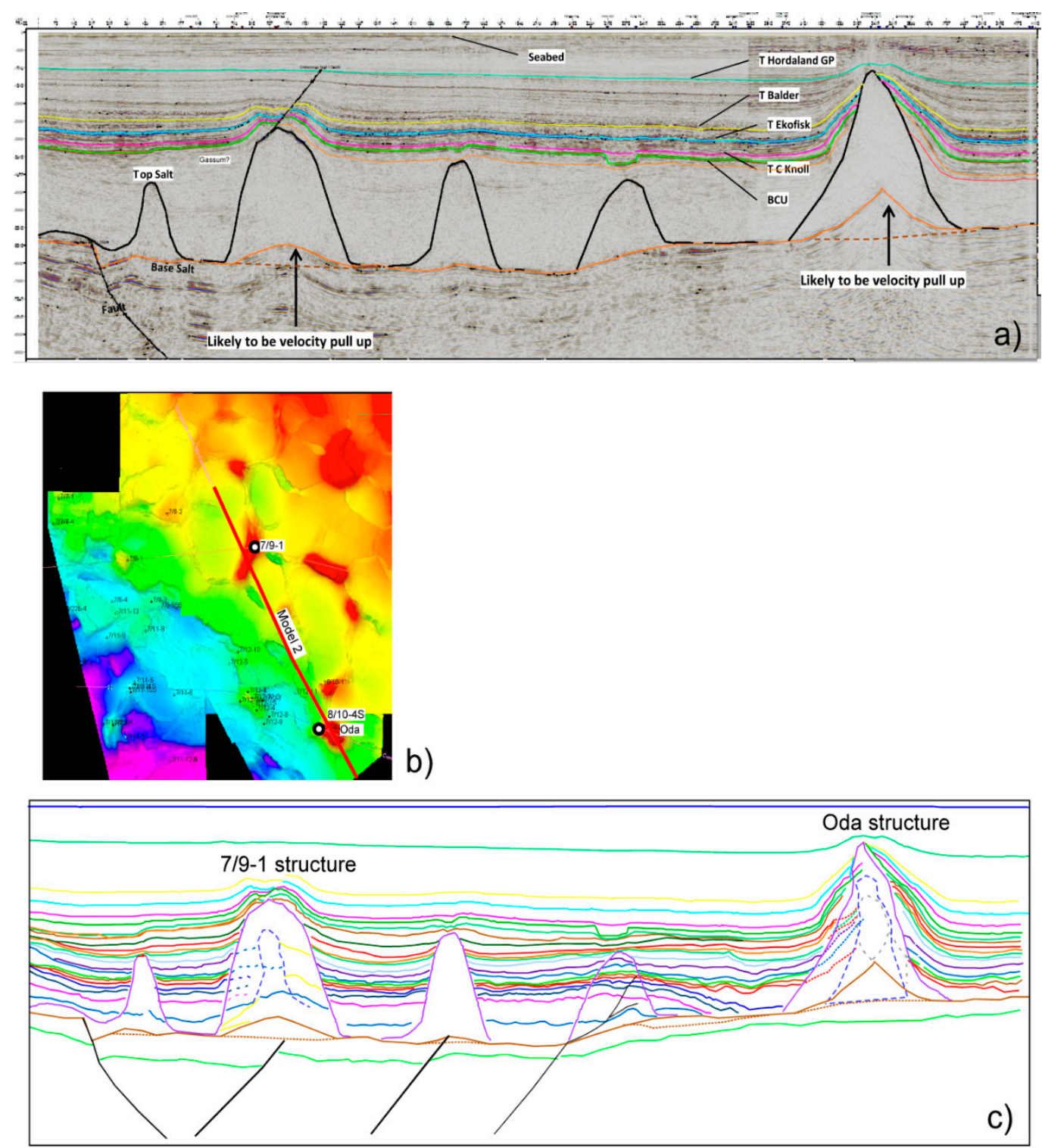

Figure 12. Interpretation of present-day structures on Model 2. (a) Interpreted depth-converted seismic section. (b) Map of Base Cretaceous horizon with the position of the modeled profile. (c) Detailed interpretation of Triassic sequences and possible interpretation within the salt structures. Continuous stratification can be interpreted through the second diapir from the right, and one can speculate if this really is a salt structure. Between this structure and the large Oda structure to the South, the lower Triassic units seem to downlap onto a paleo-slope. A stippled "core" of the largest structures indicates areas where no apparent stratification could be interpreted. In the temperature modeling, this "core" was used as a minimum-salt model.

Strongly dipping and onlapping Triassic sequences are not found on this NW-SE profile, but are commonly seen, especially in profile crossing the dip of the major WSW facing faults. These dipping 
units are related to asymmetric salt withdrawal in pods [17] and initial subsidence is related to underlying faults. It is shown by numerical modeling that subsidence in a pod basin can affect other pod basins close to it, it can also prevent subsidence, induce tilting, and cause asymmetric subsidence and even lateral translation of entire pod basins [25].

As interpretation of salt structures was uncertain, three cases was modelled, as shown in Figure 13, and used in the further geohistory- and temperature modelling.

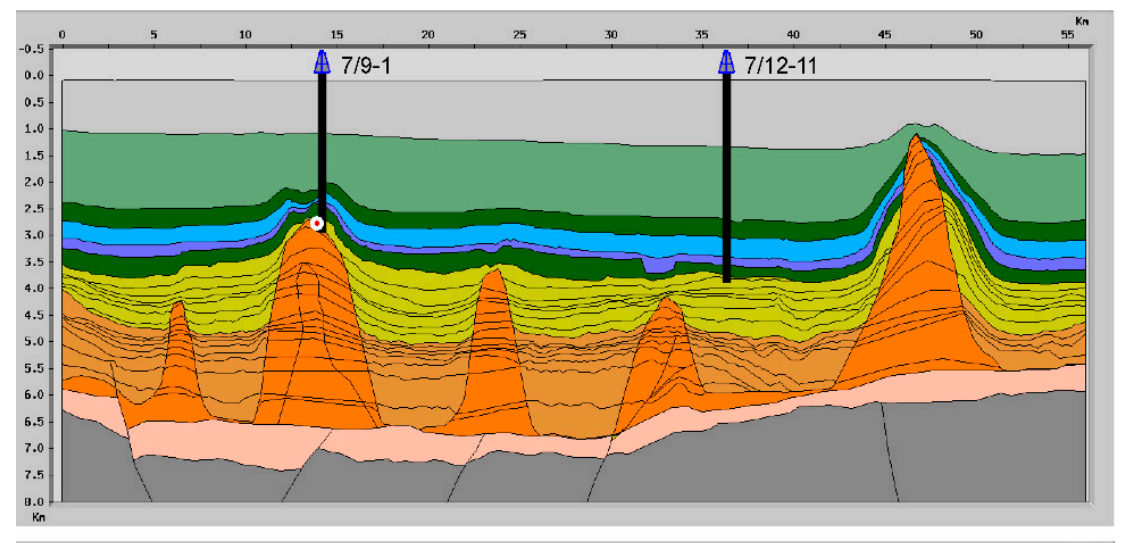

a)

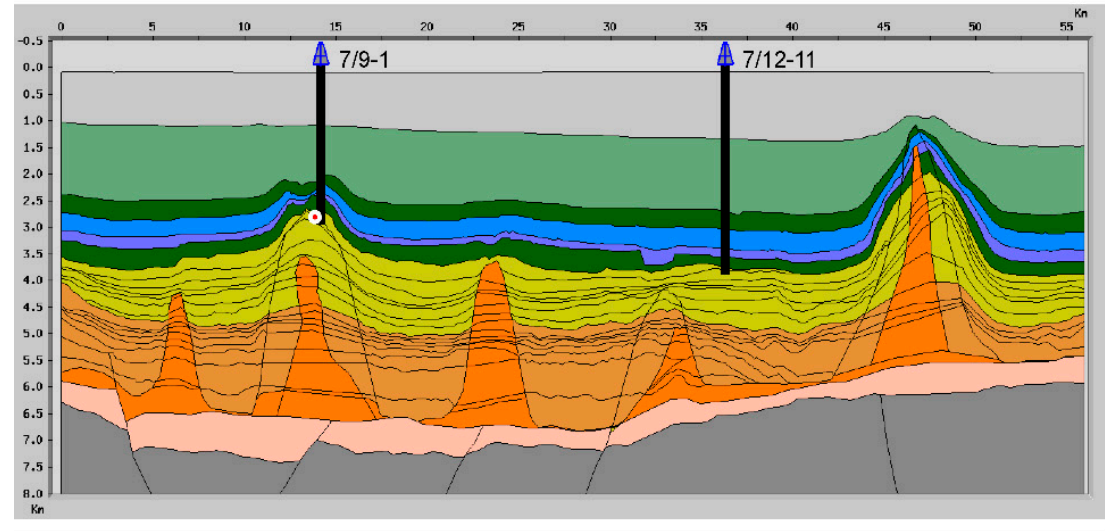

b)
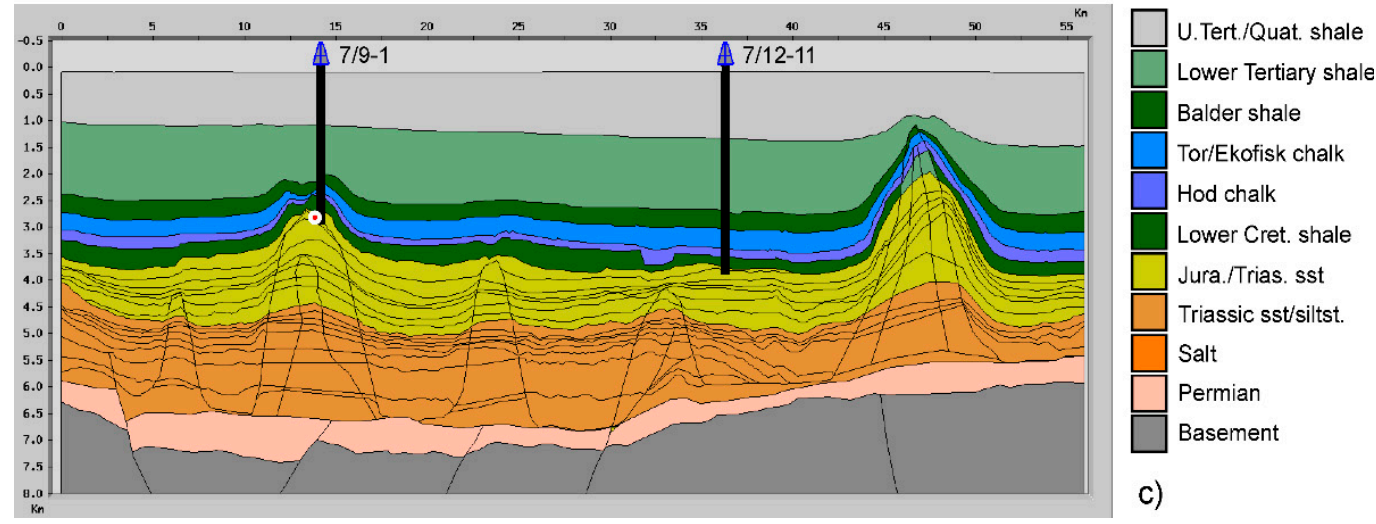

Figure 13. Present day geometry input of Model 2, colored by lithology. From top: (a) Maximum-salt model; (b) minimum-salt model; and (c) no-salt model. The locations of wells 7/9-1 and 7/12-11 are projected onto the profile.

Interpretation and sequence analysis of the Triassic sequences suggest that subsidence and development of Triassic basins (pods) started Northwest of the Oda structure relatively early in Triassic time, probably related to fault movement in the pre-salt units and basement. In Late Triassic, sediment deposition started south of the Oda structure. All the five salt-diapirs on this profile developed in parallel until latest Triassic when the minor diapirs halted, while the Oda and 7/9-1 structure continued to grow. These two structures continued to be actively growing at least into Paleogene 
times (Eocene-Oligocene). In the model, the structure at $\sim 33 \mathrm{~km}$ (second structure from right) reached a maximum height at Base Cretaceous time and lost volume and height in Cretaceous time as the graben above developed and salt-mass was lost to the sides. Some of the time-steps reconstructed in the geohistory are shown in Figure 14.
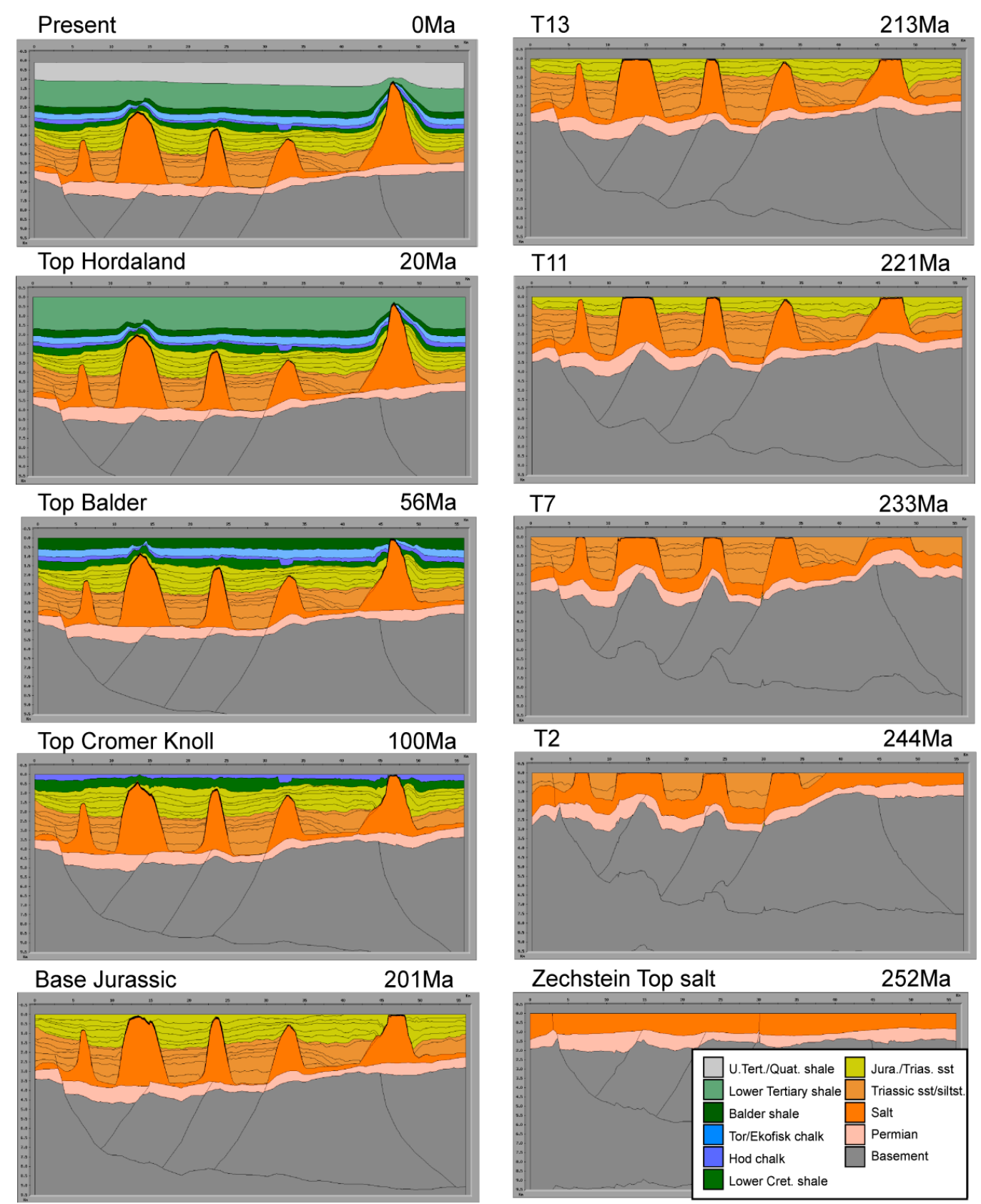

Figure 14. Geohistory reconstruction of Model 2. The figure shows 10 of the total 24 time-steps in the model, including 14 time steps during Triassic time.

\section{Modelling of Temperature History and Vitrinite Reflectance}

BMT utilizes finite difference calculations by conduction with a rectangular finite difference grid of varying sizes (cf. [23]). For every reconstructed time step in the geohistory, BMT builds a new high-resolution thermal modeling grid. Around small features, the grid size is especially fine to ensure realistic calculations. The difference grid in this study consists of a minimum of $400 \times 400$ cells of varying sizes. The spatial variation in rock properties and possible differences from one time 
step to the next are adjusted for so that appropriate finite difference calculations are maintained. The finite difference calculation by conduction is controlled by the temperatures from the previous time step, thermal conductivity (vertical and horizontal), and specific heat capacity of the basin's lithology/lithologies.

Salt has much higher thermal conductivity than the neighboring sediments (cf. Table 1). This means that a salt diapir that pierces through units of sedimentary rocks will lead heat up through the surrounding, relatively less conductive, sediments that acts as insulation. This could lead to higher temperatures in the units above salt structures and temperature depletion around the base of the salt structure.

\subsection{Temperature Effects of Salt}

\subsubsection{Synthetic Case}

To examine the temperature effect of salt, we made a simple model with a vertical salt plug over a thin salt layer (Figure 15). No thinning of the salt layer and no salt withdrawal with increased basin subsidence is used in these models. The top of the model is kept at surface at all time steps. All sediments were defined as shale.

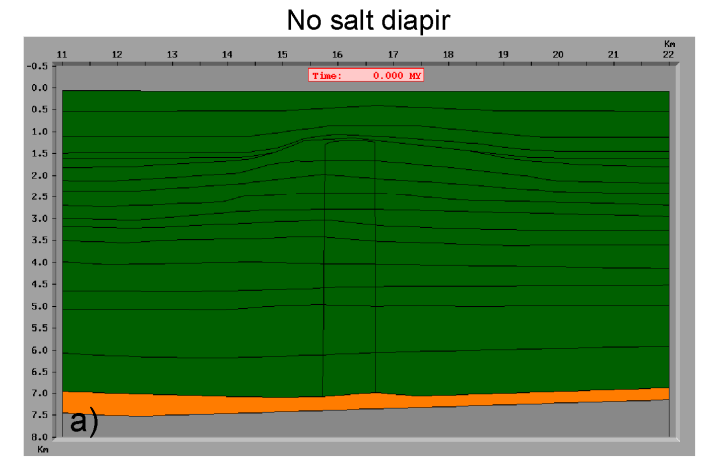

Vertical conductivity difference

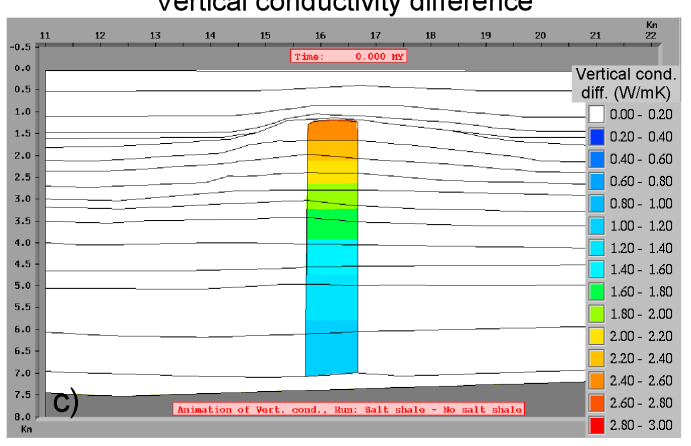

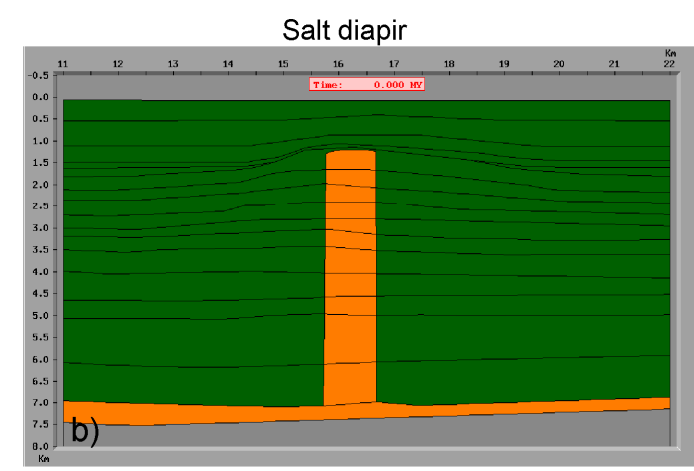

Temperature difference

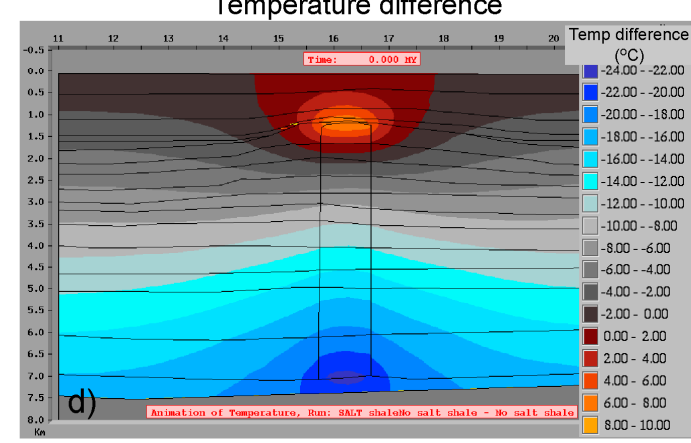

Figure 15. Temperature effect of salt in the synthetic simple model. B) Model without salt diapir, (a,b) with salt diapir (orange). (c) Difference in thermal conductivity between the two models, (d) temperature difference between the two models. Grey to blue colors: Colder sediments in salt diapir model. Brown to red colors: Higher temperature in diapir model.

The thermal conductivity of salt is strongly temperature dependent, described by a temperature correction factor $\alpha$. This factor is used in the following manor to correct thermal conductivity values (equation modified from Reference [26]):

$$
\lambda=\operatorname{\lambda ref} \frac{\lceil 1\rceil}{\lfloor 1+\alpha T\rfloor}
$$

where: 
$\lambda \quad$ is the corrected thermal conductivity in $\mathrm{W} / \mathrm{m}^{\circ} \mathrm{C}$

$\lambda_{\text {ref }}$ is the thermal conductivity calculated at the reference temperature in $\mathrm{W} / \mathrm{m}^{\circ} \mathrm{C}$.

$\alpha$ is temperature correction factor in $1 /{ }^{\circ} \mathrm{C}$, assumed here to be $5.0 \times 10^{-3}{ }^{\circ} \mathrm{C}$

$T$ is the temperature in ${ }^{\circ} \mathrm{C}$

Figure 15 shows the input profile with and without salt and the resulting temperature effects. The resulting effect on temperature is clearly seen in the temperature difference plot in Figure 15d where the model with salt diapir has significantly higher temperatures in the sediments above the top of the salt structure (brown to red colors), and colder sediments (grey to blue colors) at depth relative to the case without the salt diapir. These simple models demonstrate that the conductivity difference between salt and sediments play an important role in temperature distribution around salt structures.

\subsubsection{Temperature History of Model 1}

Model 1 is modeled with and without salt structures. The first model follows the evolution of salt structures of Figure 11. The second model has continuous sedimentary units and a uniformly thin salt unit at the base throughout the geohistory. Figure 16 shows the reconstructed geometries at two time steps (20 Ma and $60 \mathrm{Ma}$ ) and the temperature difference between these two models.

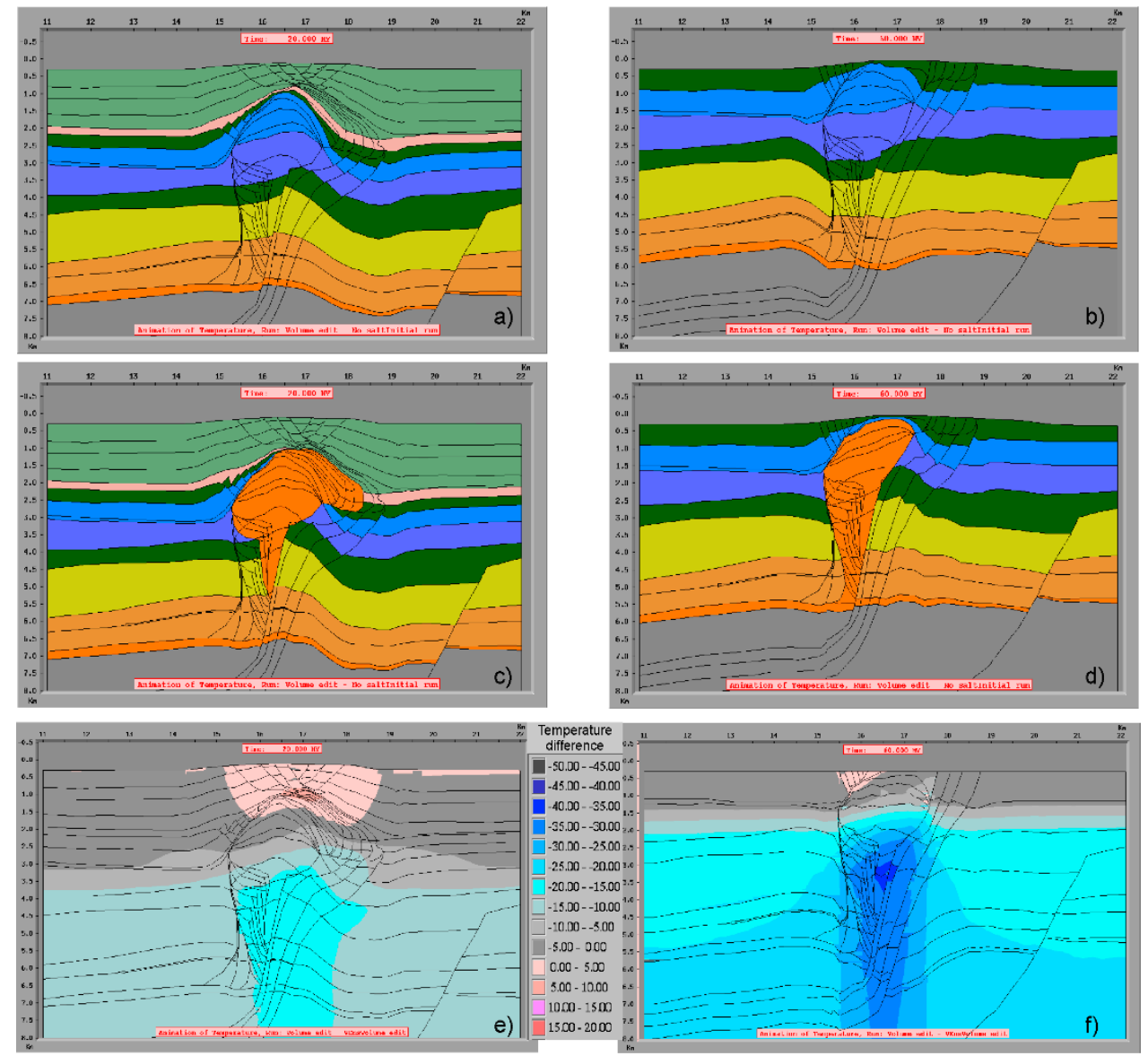

Figure 16. (a-d) Reconstructed geometries at $20 \mathrm{Ma}(\mathbf{a}, \mathbf{c})$ and $60 \mathrm{Ma}(\mathbf{b}, \mathbf{d})$ without and with salt structures, Figure $(\mathbf{e}, \mathbf{f})$ shows the temperature differences between the two models; temperature cooling in blue colous and temperature increase as pink to red colors.

At $60 \mathrm{Ma}$ the salt structure is still continuous and a strong vertical cooling effect is seen along the salt. At $20 \mathrm{Ma}$ the salt balloon is broken free from its stem and the vertical cooling is less. The relatively hotter, isolated, salt balloon volume leaks heat upward into the shallow sediment section above. 
The temperature differences in these two models could be up to $+5-10{ }^{\circ} \mathrm{C}$ above the salt at $20 \mathrm{Ma}$ and $-35-40^{\circ} \mathrm{C}$ in the salt stem. The paleo heat flow was constant across the profile and calculated by two tectonic events in the area: A Permo-Triassic event and an Earliest Cretaceous event.

In the model, the entire width of the profile is affected by the temperature change. Deeper than $2 \mathrm{~km}$, the temperatures are generally lowered with the existence of salt, increasingly towards the stem of the salt structure. Increased temperature due to the salt structure is only seen in the upper part of the salt balloon and directly above it. The largest difference in the sediments is found around the stem of the salt balloon during Latest Cretaceous time (75 Ma) (see Figure 17), whereas maximum heating of the area above salt occurred in Miocene time. The maximum modeled temperature reduction was between $84.7^{\circ} \mathrm{C}$ at $75 \mathrm{Ma}$ (Point 3 in Figure 17). A maximum positive temperature difference of only $5.8^{\circ} \mathrm{C}$ was modeled directly above the highest point of the salt structure at base Miocene time (point 1 in Figure 17). An intermediate point in the chalk unit (point 2) shows a maximum temperature reduction in the salt model of $24^{\circ} \mathrm{C}$ at $75 \mathrm{Ma}$.
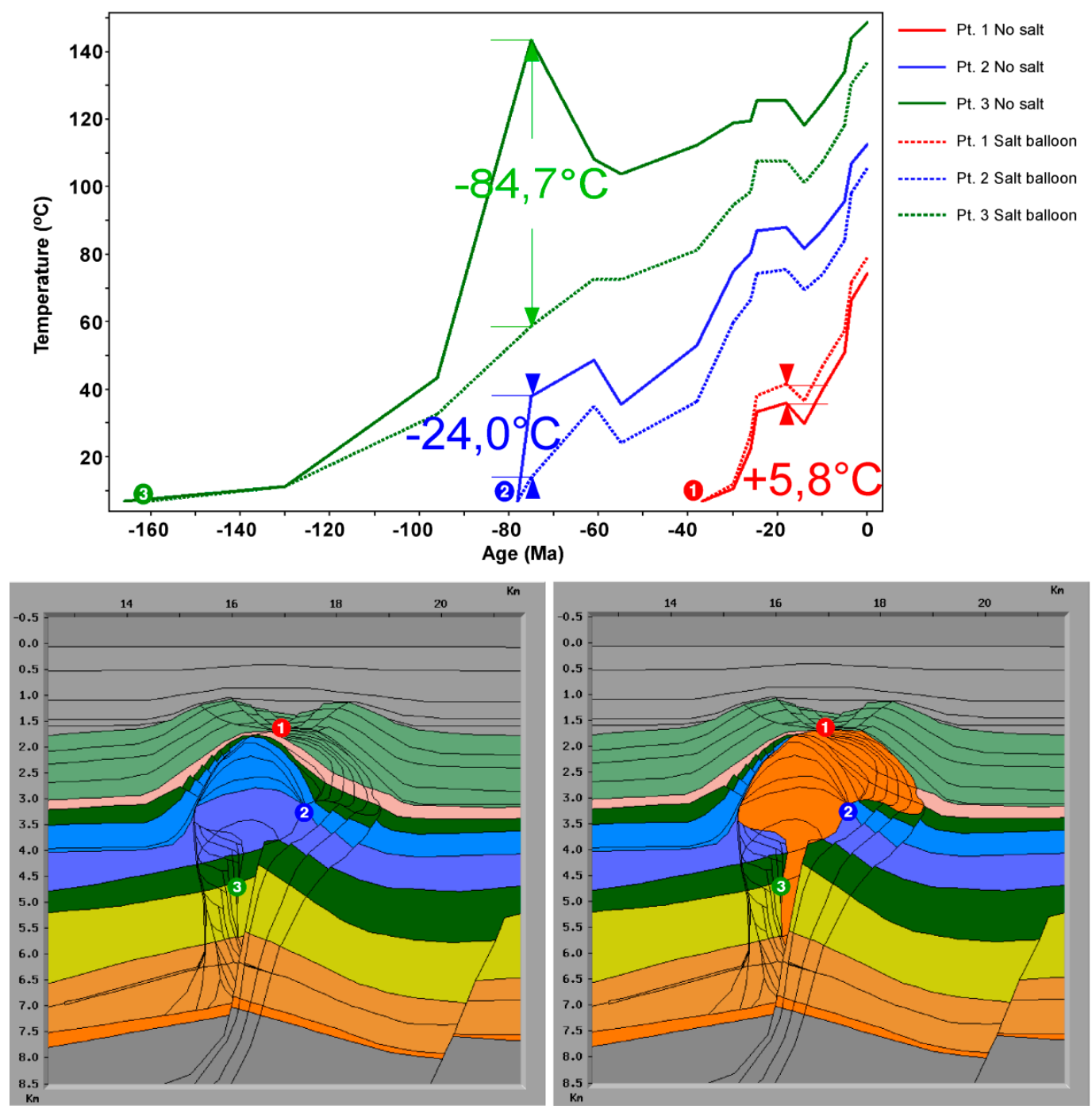

Figure 17. Temperature history difference in models with and without the growth of a salt balloon structure. The curves show temperature history of the points 1,2, and 3 given on the two model profiles. The temperature of point 1 above the salt increases by $5.8^{\circ} \mathrm{C}$ in the salt balloon model, whereas the lowest point below salt shows a decrease of more than $84^{\circ} \mathrm{C}$ in salt model. 


\subsubsection{Model 2}

Due to the uncertainty in interpretation of the salt bodies on Model 2, we have made three modeling options for determination of the temperature history and maturation (shown in Figure 13). The temperature over the profile was calculated based on thermal conductivities of the sediments (as a function of porosity; given in Table 1) and the modeled palaeo heat flow.

In Reference [26], the authors have found significant anisotropy in the thermal conductivities of shales in the North Sea. This is taken into account in our study. The vertical and horizontal thermal conductivities are shown in Figure 18a.

The palaeo heat flow was calculated by two tectonic events in the area; a Permo-Triassic event and a Mid-Jurassic to Earliest Cretaceous event; see more details in Reference [22]. The effect of the salt body on temperature history for a selected point (location; Figure 13c) above the salt is shown in Figure $18 \mathrm{~b}$. The calculated temperature is, as expected, the highest for the maximum-salt model.
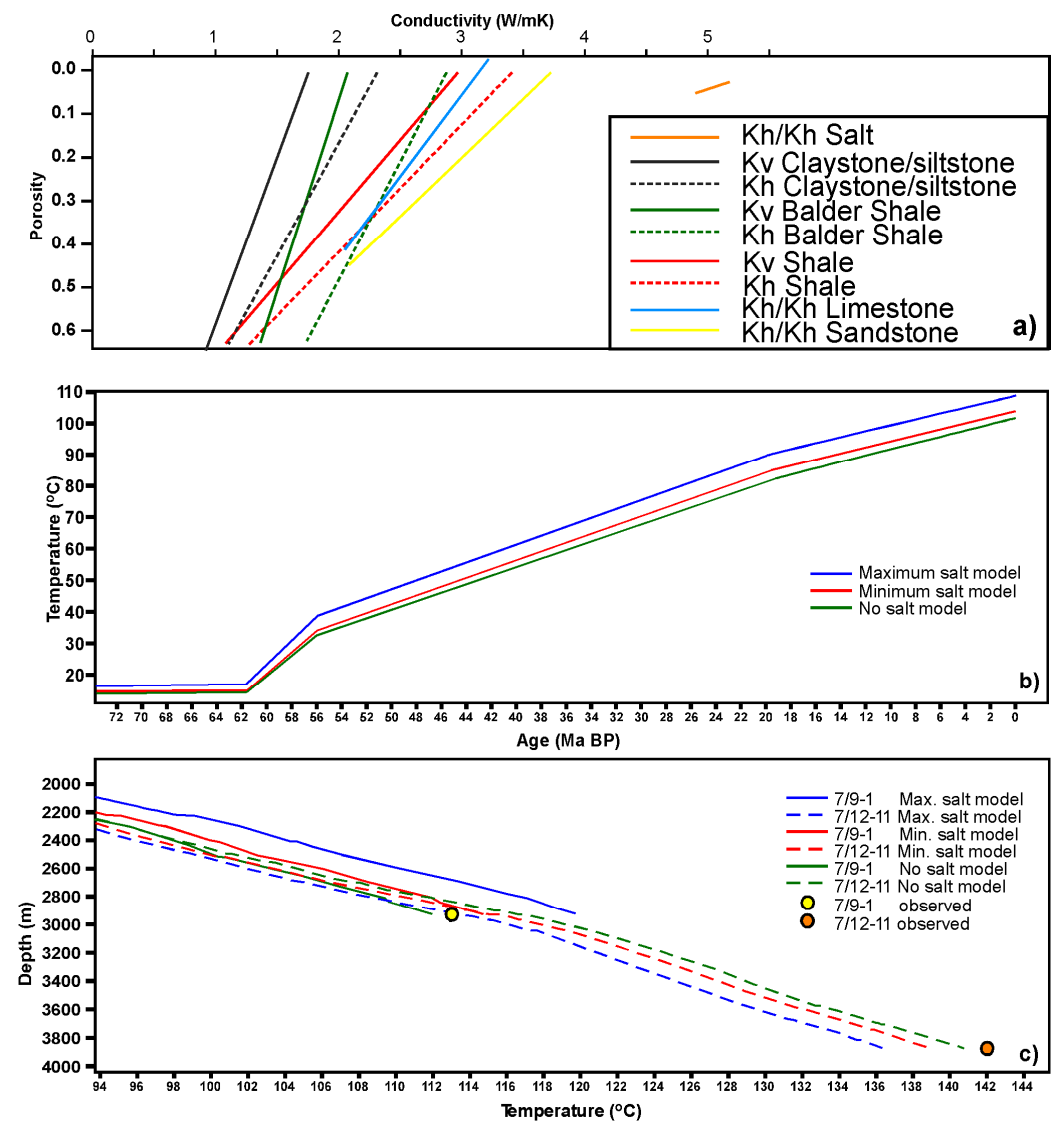

Figure 18. Thermal conductivity and temperature history for the three salt models shown in Figure 13. (a) Thermal conductivities used in the modeling. $\mathrm{Kv}=$ vertical conductivity, $\mathrm{Kh}=$ horizontal conductivity. Note that shale and claystones have different $\mathrm{Kv}$ and $\mathrm{Kh}$. Other lithologies have uniform conductivities in both directions. (b) Calculated temperature history for the point above the salt close to base of well 7/9-1 (position shown in Figure 13). (c) Present day calculated and observed temperature in wells 7/9-1 and $7 / 12-11$.

The present day heat flow is found by calibration to present day temperature. The calculated versus observed present day temperatures for the wells 7/9-1 and 7/12-11 are shown in Figure 18c. The calculated present day temperature difference is approximately $10{ }^{\circ} \mathrm{C}$ between the max-salt model and no-salt model. We have used uniform heat flow over the profile and the same matrix thermal conductivities within the various sedimentary units over the profile. Based on these assumptions, we see that the best match with the observed temperature in well 7/9-1 is given by the minimum-salt 
option and the no-salt option. The largest discrepancy is given by the max-salt option. A better fit for the max-salt option could be achieved with a reduced heat flow; however, a reduced heat flow would give larger discrepancies for well 7/12-11 for all three options; the three options are already at the lower possible range.

Figure 19 compares the present day temperatures on the models with no salt and maximum salt, as defined in Figure 13. In the model with salt, isotherm curves rise above the upper part of the salt columns, but dip down in the deepest part of the salt and below the salt columns. The increase in temperature can be visible at least $2400 \mathrm{~m}$ above the top of the large salt column at position $13 \mathrm{~km}$ on the modeled profile. At the base of the intra-salt basins, the temperatures are lowered by about $20{ }^{\circ} \mathrm{C}$. At the top of the salt columns, the temperature increases up to $8.5^{\circ} \mathrm{C}$, most above the highest ones.

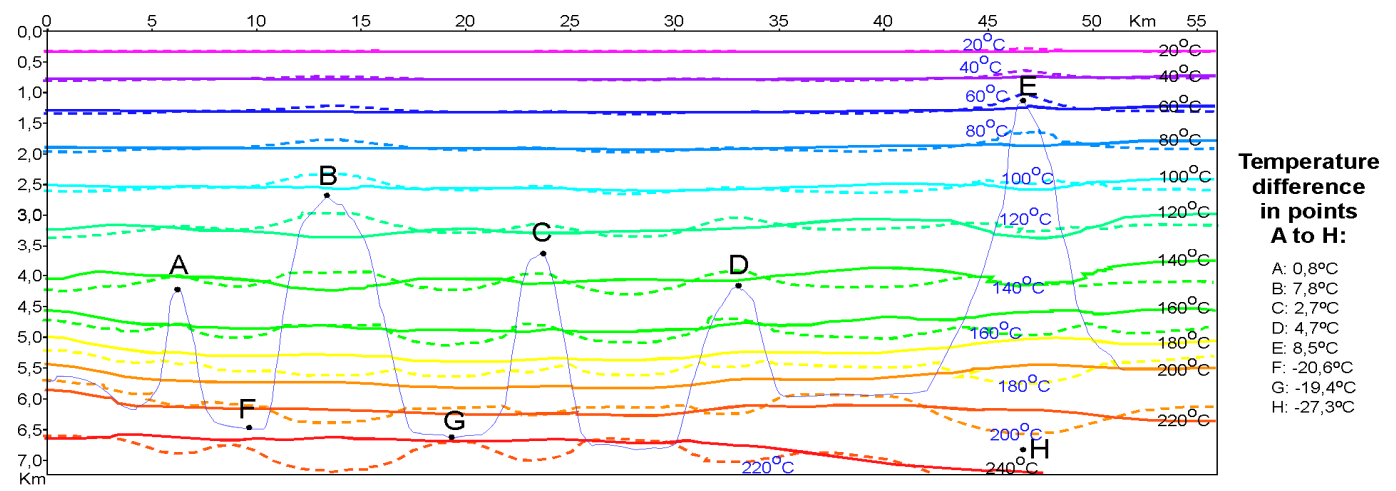

Figure 19. Calculated present-day temperature for models with salt and without salt. The temperature isotherm curves for the model with salt (stippled lines and blue temperature numbers), and the model without salt (continuous lines, black temperature numbers). In the salt model points A-D show higher temperatures than in the model without salt. Points F-H show lower temperatures in the salt model.

\subsection{Vitrinite Reflectance}

Vitrinite is an organic material from cell walls of woody plant tissue [27]. Vitrinite reflectance $(\mathrm{VR})$ is a measure of the percentage of incident light reflected from the surface of vitrinite particles in a sedimentary rock. It is referred to as \%Ro. Results are often presented as a mean Ro value based on all vitrinite particles measured in an individual sample. Vitrinite reflectance is a standard method for measuring the thermal maturity of sedimentary rocks and kinetic models of vitrinite reflectance are commonly used to constrain paleo thermal histories in basin and petroleum system modeling. BMT uses the EASY\%RO model to calculate vitrinite reflectance [28]. Generally, the onset of oil generation is correlated with a reflectance of $\%$ Ro $=0.5-0.6 \%$ and the termination of oil generation with reflectance of $0.85 \%-1.1 \%$. The onset of gas generation ('gas window') is typically associated with \%Ro values of $1.0 \%-1.3 \%$ and terminates around $3.0 \%$. The vitrinite reflectance was here modeled for cases with and without development of piercing salt structures for both models, and the results are shown in Figures 20 and 21.

In model 1, the increased conductivity of the salt and the resultant higher sediment temperatures above salt and lower temperatures below and around the salt clearly affects the modeled vitrinite reflectance (Figure 20). The same can be seen, but less pronounced, in Model 2 with the five columnar diapirs (Figure 21). The hydrocarbon potential may be lower in areas around penetrating salt structures, as cooling of the sediments around the stem of the salt structure lowers the maturation potential locally. This may be enhanced by erosion over the salt diapirs.

The temperature effects in the area above salt are not sufficient to have significant hydrocarbon potential in Model 1 (Figure 20). The model with salt has only $<0.05 \%$ higher VR at shallow depths and increasingly lower VR towards the stem below salt with a maximum difference of $0.6 \%-1.0 \%$ lower VR at $7 \mathrm{~km}$ depth in the lower Triassic sequence. 
No salt model Vitrinite reflectance
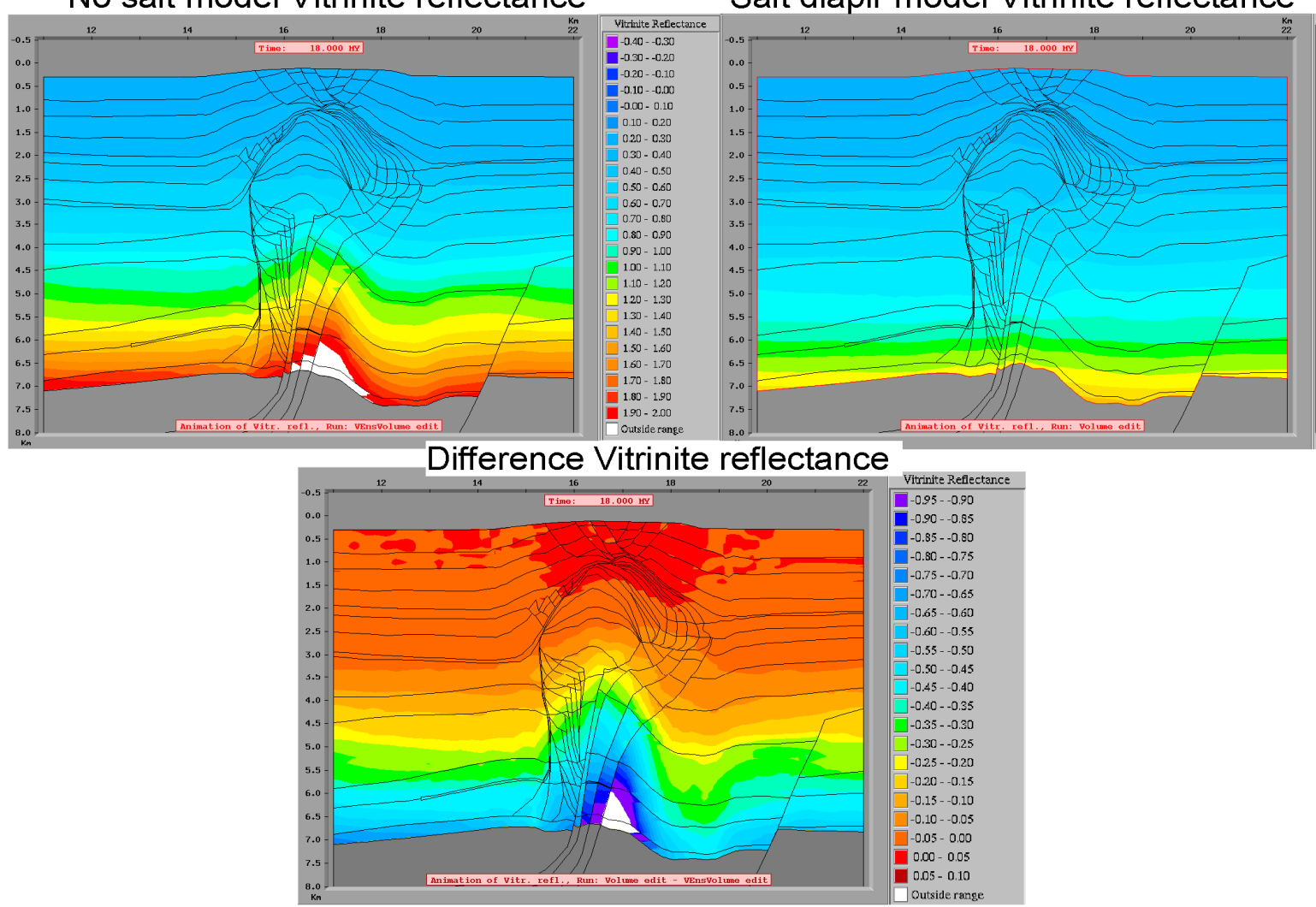

Figure 20. Top: Modeled vitrinite reflectance for Model 1 at $18 \mathrm{Ma}$, without salt balloon (top left) and model with salt balloon (top right). Lower figure shows the difference in modeled vitrinite reflectance between the two models.

The calculated present day vitrinite reflectance difference between the models with and without salt structures for Model 1 and Model 2 are shown in Figure 21. The modeled "oil windows" and "gas windows" are indicated by light green and red colors for the no-salt models and with hatching on the salt-structure models. Models with salt diapirs have lower maturation in the basins between salt structures than models without salt diapirs. In general, the VR difference increases by depth from around $2 \mathrm{~km}$ depth, with lower Ro values (less mature sediments) in the salt-diapir models. Maturation is higher above salt diapirs, but only at shallow depths and has little impact on hydrocarbon potential.

In Model 1, a maximum depth difference of $-1065 \mathrm{~m}$ at the base of the "gas window" is shown towards the salt stem. At Ro $=1.0$ (base of "oil window" the maximum depth difference is $-935 \mathrm{~m}$ (Figure 21a). The salt modeled option may still be gas generating in the Jurassic and upper Triassic below the salt structure, while the model without the salt balloon has a present day "gas-window" that only reaches down into Lower Cretaceous strata.

Along the profile in Model 2, the VR difference decreases upward, but the salt model has consistently lower \%Ro values in the Triassic pod basins relative to the no-salt model. At a position $30 \mathrm{~km}$ along the profile \%Ro values of 3.0 are found $600 \mathrm{~m}$ shallower in the no-salt model. As expected from the temperature modeling, the oil and gas windows are deeper between salt pillars than in the model without salt. Maximum depth of oil window is as much as $264 \mathrm{~m}$ deeper centrally in the Triassic pod at position $20 \mathrm{~km}$ in the salt model (marked A in Figure 21b). Above the salt structure at $33 \mathrm{~km}$, the salt model reaches base of oil window (i.e., Ro $=1.1$ ) at $203 \mathrm{~m}$ shallower depth than in the no-salt model (marked B). The resulting vitrinite reflectance models indicate that the Triassic sequences of Model 2 may still be gas-generating presently. 

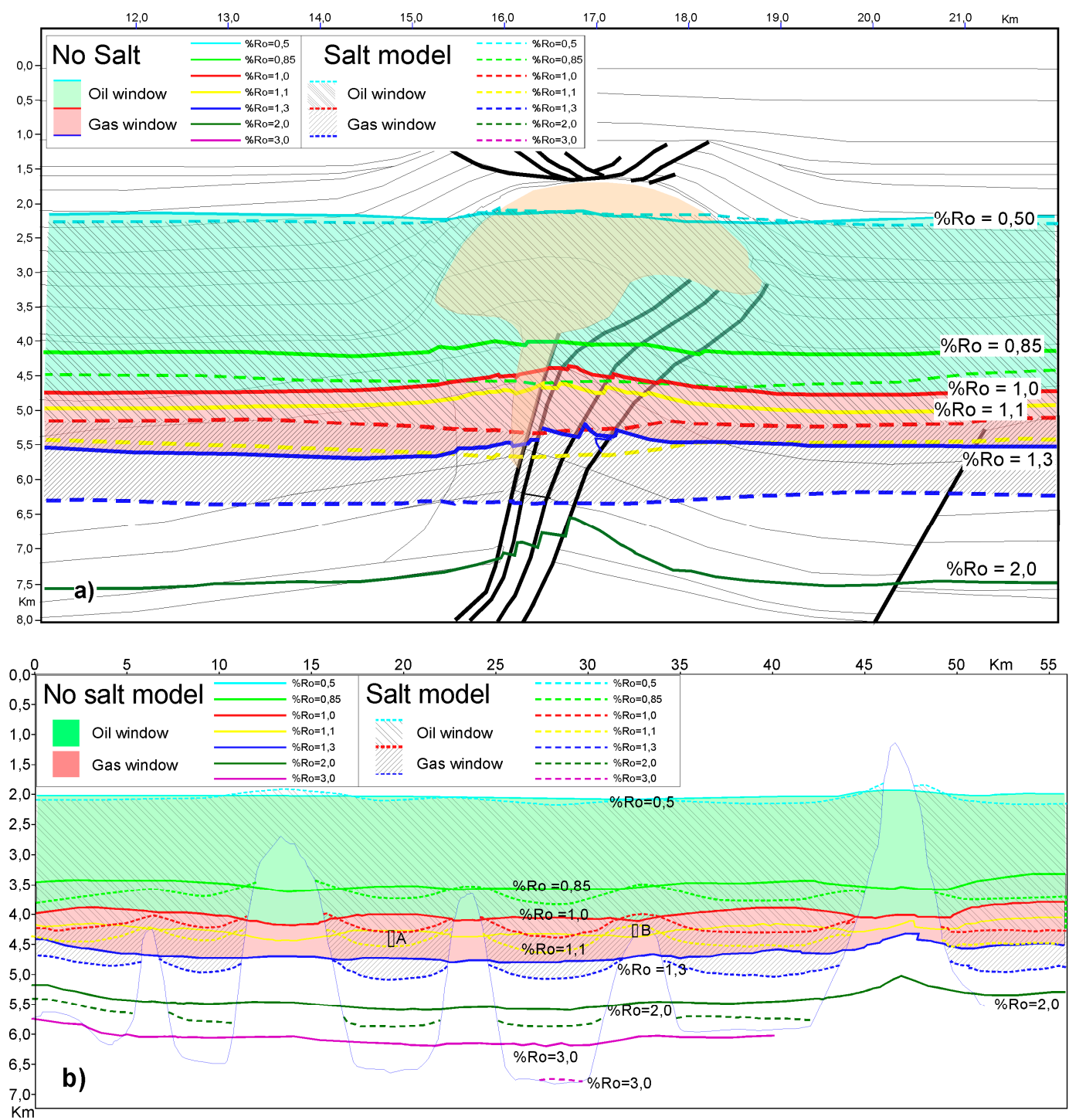

Figure 21. Differences in modeled Vitrinite Reflectance at present day geometry between models with salt (stippled lines) and model without salt diapirs (solid lines). "Oil-window" and "gas-windows" are indicated between \%Ro values of 0.5-1.0 and 1.0-1.3, respectively. (a) model 1, (b) model 2.

\section{Discussion}

This study has demonstrated the importance of high resolution basin modeling for understanding the dynamic evolution of basin geometry, structures, temperature and maturity- history in areas with salt structures. Development of salt structures and surrounding pod basins is a self-reinforcing process. Increased subsidence starts salt movement and initiates the chain of movements leading to buoyant movement and piercing of salt structures. In this process, salt thins and withdraws from the deepest basins and move towards the salt structures, leaving room for sediment accommodation and subsidence. This structural development may affect the pattern of heat distribution

Since salt has very unique rheological properties it is vital to have the possibility to reconstruct a reasonable geometry and temperature evolution. In modeling of salt structures interpretation is probably the largest uncertainty, and it is important to have a good definition of lithologies in the model, as the conductivities of different lithologies vary a lot (Figure 18a). As shales due to their layered nature of flattened clay minerals, have substantially higher horizontal conductivity than vertical conductivity [29], they transfer heat horizontally and act as insulators vertically. Salt, sandstones, and carbonates have equal horizontal and vertical-conductivity. 
As shown in this study and previous studies [2,14], the presence of salt can have a large impact on the local temperature distribution within an area, and the higher conductivity of salt plays an important role both for evolution of reservoir and traps and for defining areas of optimal temperature and maturation. Our results are in good correspondence to the modeling results of Reference [14], which modeled a maximum temperature lowering of $85^{\circ} \mathrm{C}$ at the base of a salt diapir reaching the surface, and similar vitrinite reflectance lowering around a salt diapir relative to a similar geometry shale diapir.

For petroleum exploration in a salt environment, the geometric evolution in time and space is important. Results of geohistory reconstruction and basin modeling are important for understanding the evolution of both reservoirs and traps in space and time. A good model for the evolution of basin geometry and salt volume is essential to make a good temperature and maturation model. Modeling of geological processes always involves strong simplification and general assumptions based on experience and knowledge about the area and processes that are modeled. The quality of the model is directly related to the quality of the input data. The input parameters used must be based on the best possible knowledge, but will always represent an amount of uncertainty. In our models, the quality of seismic interpretation and definition and distribution of lithological units are very important. The seismic interpretation is probably the largest uncertainty in this modeling, but other input parameters may contribute to the uncertainties. Repeated modeling with sensitivity analysis of uncertain parameters, with calibration to measured data is important to reduce these uncertainties.

To model a complex evolution of salt-structures, it is necessary to use basin modeling software that allows very high and variable resolution, both in time and space. The BMT modeling software nicely fits to these requirements, which are important to be able to model the evolution of complex geometries of salt structures and their temperature and maturity effects.

Additional important effects of active salt development are better understanding and observation of fracturing above piercing salt structure, faulting and deformation related to salt withdrawal and basin collapse, erosion above salt structure and redistribution of potential reservoir sediments and others.

Late regional phases of erosion could strongly affect the geometry and temperature history in a salt basin and correct modeling of these episodes are important. A salt structure reaching the surface is considered to be a very effective conductor draining a the basin of heat [14].

The lowered temperature below salt can delay and extend the time of hydrocarbon generation and preserve source rocks even in a relatively deep basin. This factor may thus be important in late and rapidly evolving salt areas, such as on continental margins where subsidence and maturation occurred late in parallel to the evolution of the complex salt structures.

Salt movement up through carbonates may also lead to substantial dissolution of carbonate [30] that may precipitate as carbonate-cement in fractured reservoir units, ruining reservoir quality. These processes are, however, beyond the scope for this article.

\section{Conclusions}

Detailed study of seismic data from our study area revealed a complex development of salt structures since early Triassic time, involving both the extensional and compressional phases.

Our detailed modeling has recreated the salt evolution and shown that the presence of salt structures have a substantial effect on temperature and maturation, both close to the salt itself, and in a larger distance around and below salt structures.

The results show that basin areas at least $3-5 \mathrm{~km}$ to the sides of the salt structures are affected by lowered temperatures and maturation. The conductivity effect of salt increases toward the surface and thus salt structures near or at the surface are more efficient at draining heat out of the basin.

Temperatures increase in the sediments above the salt structures, but this has very little impact on maturation, because the heated sediments are too shallow and the temperature increase too small to increase maturation potential. The cooling of the sediments around salt structures may play a larger role as it affect larger areas and in deeper units. Cooling of the sediments due to presence of salt may be a very important factor in hydrocarbon exploration in regions with salt structures. 
The geometry of the present day salt and its history of development are very important. A vertical columnar salt diapir will have a symmetrical temperature anomaly around the salt. If an irregular salt geometry develops with a shallow overhanging salt volume, an increased temperature anomaly would occur below the salt overhang, possibly preserving maturation in the position of stratigraphic traps. A larger area above the salt is also affected by heating than for a narrow columnar structure. Our modeling software allows modeling of complex development of such overhanging salt structures.

A simple salt anticline or a vertical salt column still connected to the initial salt layer has the largest salt volumes at depth where the conductivity-contrast to the surrounding sediments is the least. A detached allochtonous salt volume [2] or a canopy or mushroom-shaped salt structures have most of its salt volume at shallower depths where they can more effectively drain the heat from sediments below.

In our modeling, the effects on maturation occur at depths below $2 \mathrm{~km}$, and at depths of more than $3.5-4 \mathrm{~km}$ the maturation levels are lowered as much as $500 \mathrm{~m}$ in pod-basins between vertical diapirs and as much as $1-1.5 \mathrm{~km}$ below and overhanging mushroom-shaped salt structure. This shows that the effect is substantial enough that it should be considered when exploring for hydrocarbons in salt regions.

Author Contributions: Conceptualization, I.G. and A.M.; methodology, I.G.; software, I.G.; validation, I.G. and A.M; investigation, I.G.; writing—original draft preparation, I.G. and A.M.; writing—review and editing, I.G. and A.M.; project administration, I.G.; funding acquisition, I.G.

Funding: This research received no external funding.

Acknowledgments: First we have to thank LOTOS Exploration and Production Norge AS (LEPN), the operator of PL 498/B, for letting us publish results based on their data, for their valuable input and help with expertise and data. Also thanks to the partners in PL 498/B; Skagen 44, Edison, North and Lime. Thanks to Willy Fjeldskaar, Ingrid F. Løtveit and two anonymous reviewers for constructive comments and suggestions.

Conflicts of Interest: The authors declare no conflict of interest.

\section{References}

1. Alsop, G.I.; Archer, S.G.; Hartley, A.J.; Grant, N.T.; Hodgkinson, R. Salt Tectonics, Sediments and Propectivity; Special Publication, Geological Society: London, UK, 2012; 632p.

2. Jackson, M.P.A.; Hudec, M.R. Salt Tectonics: Principles and Practice; Cambridge University Press: Cambridge, UK, 2017; 510p.

3. Stewart, S.A.; Clark, J. Impact of salt on the structure of the Central North Sea hydrocarbon fairways. In Petroleum Geology of Northwest Europe: Proceedings of the 5th Conference; Fleet, A.J., Boldy, S.A.R., Eds.; Geological Society: London, UK, 1999; pp. 179-200.

4. Alsop, G.I.; Weinberger, R.; Marco, S.; Levi, T. Faults and fracture patterns around a strike-slip induced salt wall. J. Struct. Geol. 2018, 106, 103-124. [CrossRef]

5. Trusheim, F. Mechanism of salt migration in Northern Germany. AAPG Bull. 1960, 44, 1519-1540.

6. Zong, J.; Coskun, S.; Stewart, R.R.; Dyaur, N.; Myers, M.T. Salt densities and velocities with application to Gulf of Mexico salt domes. In Salt Challenges in Hydrocarbon Exploration SEG Annual Meeting Post-Convention Workshop; Society of Exploration Geophysicists: New Orleans, LA, USA, 2015; Available online: http: //www.agl.uh.edu/pdf/jingjing-salt\%20densities.pdf (accessed on 24 March 2019).

7. Blackwell, D.D.; Steele, J.L. Thermal conductivity of sedimentary rocks: Measurements and significance. In Thermal History of Sedimentary Basins; Naeser, N.D., McColloh, T.H., Eds.; Springer: New York, NY, USA, 1989; pp. 13-37.

8. Gussow, W.C. Salt diapirism: importance of temperature and energy source of emplacement. In Diapirism and Diapirs; Baraunstein, J., O’Brien, G.D., Eds.; AAPG Mem: Tulsa, OK, USA, 1968; Volume 8, pp. 16-52.

9. Urai, J.L. Deformation of Wet Salt Rock. Ph.D. Thesis, University of Utrecht, Holland, The Netherlands, 1983. (Referred in Price and Cosgrove, 1990) Unpublished.

10. Price, N.J.; Cosgrove, J.W. Analysis of Geological Structures; Cambridge University Press: Cambridge, UK, 1990; 502p. 
11. Jackson, M.P.A.; Talbot, C.J. External shapes, strain rates and dynamics of salt structures. Geol. Soc. Am. Bull. 1986, 97, 305-323. [CrossRef]

12. Hudec, M.R.; Jackson, M.P.A. Terra infirma: Understanding salt tectonics. Earth-Sci. Rev. 2007, 82, 1-28. [CrossRef]

13. Brun, J.-P.; Fort, X. Salt tectonics at passive margins: Geology versus models. Mar. Pet. Geol. 2011, 28, 1123-1145. [CrossRef]

14. Mello, U.T.; Karner, G.D.; Anderson, R.N. Role of salt in restraining the maturation of subsalt source rocks. Mar. Pet. Geol. 1995, 12, 697-716. [CrossRef]

15. Baniak, G.M.; Gingras, M.K.; Burns, B.A.; Pemberton, S.G. An example of a highly bioturbated, storm-influenced shoreface deposit: Uper Jurassic Ula Formation, Norwegian North Sea. Sedimentology 2014, 61, 1261-1285. [CrossRef]

16. Hodgson, N.A.; Farnsworth, J.; Fraser, A.J. Salt-related tectonics, sedimentation and hydrocarbon plays in the Central Graben, North Sea, UKCS. Geol. Soc. Lond. Spec. Publ. 1992, 67, 31-63. [CrossRef]

17. Karlo, J.F.; van Buchem, F.S.P.; Moen, J.; Milroy, K. Triassic-age salt tectonics of the Central North Sea. Interpretation 2014, 2, SM19-SM28. [CrossRef]

18. Mannie, A.S.; Jackson, C.A.L.; Hampson, G.J. Shallow-marine reservoir development in extensional diapir-collapse minibasins: An integrated subsurface case study from the Upper Jurassic of the Cod terrace, Norwegian North Sea. AAPG Bull. 2014, 98, 2019-2055. [CrossRef]

19. Mannie, A.S.; Jackson, C.A.L.; Hampson, G.J.; Fraser, A.J. Tectonic controls on the spatial distribution and stratigraphic architecture of net-transgressive shallow- marine synrift succession in a salt-influenced rift basin: Middle to Upper Jurassic, Norwegian Central North Sea. J. Geol. Soc. 2016, 173, 901-915. [CrossRef]

20. Høiland, O.; Kristensen, J.; Monsen, T. Mesozoic evolution of the Jæren High area, Norwegian Central North Sea. In Petroleum Geology of Northwest Europe: Proceedings of the 4th Conference; Parker, J.R., Ed.; Geological Society: London, UK, 1993; pp. 1189-1195.

21. Pegrum, R.M. Structural development of the south-western margin of the Russian-Fennoscandian Platform. In Petroleum Geology of the Northern European Margin; Spencer, A.M., Ed.; Graham \& Trotman: London, UK, 1984; pp. 173-189.

22. Fjeldskaar, W.; Ter Voorde, M.; Johansen, H.; Christiansson, H.P.; Faleide, J.I.; Cloetingh, S.A.P.L. Numerical simulation of rifting in the northern Viking Graben: the mutual effect of modelling parameters. Tectonophysics 2004, 382, 189-212. [CrossRef]

23. Fjeldskaar, W.; Andersen, Å.; Johansen, H.; Lander, R.; Blomvik, V.; Skurve, O.; Michelsen, J.K.; Grunnaleite, I.; Mykkeltveit, J. Bridging the gap between basin modelling and structural geology. Reg. Geol. Metallog. 2017, $72,65-77$.

24. Sclater, J.G.; Christie, P. Continental stretching: an explanation of the post-mid-Cretaceous subsidence of the Central North Sea basin. J. Geophys. Res. 1980, 85, 3711-3739. [CrossRef]

25. Fernandez, N.; Jackson, C.A.L.; Hudec, M.; Dooley, T.P. The Competition for Salt and Kinematic Interactions between Minibasins during Density-Driven Subsidence Observations from Numerical Models. 2019. Available online: https://www.researchgate.net/publication/331904078_ (accessed on 4 August 2019).

26. Burrus, J.; Audebert, F. Thermal and compaction processes in a young rifted basin containing evaporties: Gulf of Lions, France. AAPG Bull. 1990, 74, 1420-1440.

27. Crelling, J.C.; Dutcher, R.R. Principles and Applications of Coal Petrology: SEPM Short; Course. Society of Economic Paleontologists Mineralogists: Tulsa, OK, USA, 1980; Volume 8, 127p.

28. Sweeney, J.J.; Burnham, A.K. Evolution of a simple model of vitrinite reflectance based on chemical kinetics. AAPG Bull. 1990, 74, 1559-1570.

29. Fjeldskaar, W.; Prestholm, E.; Guargena, C.; Gravdal, N. Isostatic and tectonic development of the Egersund Basin. In Basin Modelling: Advances and Applications; Doré, T., Augustson, J.H., Hermanrud, C., Stewart, D.J., Sylta, Ø., Eds.; Elsevier: Amsterdam, The Netherlands, 1993; pp. 549-562.

30. Davison, I.; Alsop, G.I.; Evans, N.G.; Safarics, M. Overburden deformation patterns and mechanisms of salt diapir penetration in the Central Graben, North Sea. Mar. Pet. Geol. 2000, 17, 601-618. [CrossRef]

(C) 2019 by the authors. Licensee MDPI, Basel, Switzerland. This article is an open access article distributed under the terms and conditions of the Creative Commons Attribution (CC BY) license (http://creativecommons.org/licenses/by/4.0/). 